\title{
Pharmaceuticals, alkylphenols and pesticides in Mediterranean coastal waters: Results from a pilot survey using passive samplers
}

\author{
Dominique Munaron $^{a, *}$, Nathalie Tapie ${ }^{b}$, Hélène Budzinski ${ }^{b}$, Bruno Andral $^{c}$, Jean-Louis Gonzalez ${ }^{d}$
}

\begin{abstract}
a IFREMER, Laboratoire Environnement et Ressources du Languedoc-Roussillon, Avenue Jean Monnet, BP171, 34203 Sete Cedex, France

b Université Bordeaux 1, Laboratoire de Physico- et Toxico-Chimie de l'environnement, UMR 5255 CNRS, 351 Cours de la libération, 33405 Talence, France

c IFREMER, Laboratoire Environnement et Ressources de Provence Alpes, Cote d'Azur, Zone portuaire de Brégaillon, BP330, 83507 La Seyne-sur-Mer Cedex, France

d IFREMER, Département Biogéochimie et Ecotoxicologie, Zone portuaire de Brégaillon, BP330, 83507 La Seyne-sur-Mer Cedex, France
\end{abstract}

*: Corresponding author : Dominique Munaron, Tel : +33 499573280, Fax : +33 499573296

email address : Dominique.Munaron@ifremer.fr

\begin{abstract}
:
21 pharmaceuticals, 6 alkylphenols and 27 hydrophilic pesticides and biocides were investigated using polar organic contaminant integrative samplers (POCIS) during a large-scale study of contamination of French Mediterranean coastal waters. Marine and transitional water-bodies, defined under the EU Water Framework Directive were monitored. Our results show that the French Mediterranean coastal waters were contaminated with a large range of emerging contaminants, detected at low concentrations during the summer season. Caffeine, carbamazepine, theophilline and terbutaline were detected with a detection frequency higher than $83 \%$ in the coastal waters sampled, 4-nonylphenol (4$\mathrm{NP}$ ), 4-tert-octylphenol (4-OP) and 4-nonylphenol diethoxylate (NP2EO) were detected in all coastal waters sampled, and diuron, terbuthylazine, atrazine, irgarol and simazine were detected in more than $77 \%$ of samples. For pharmaceuticals, highest time-weighted average (TWA) concentrations were measured for caffeine and carbamazepine (32 and $12 \mathrm{ng} \mathrm{L}^{-1}$, respectively). For alkylphenols, highest TWA concentrations were measured for 4-nonylphenol mono-ethoxylate and 4-nonylphenol (41 and $33 \mathrm{ng} \mathrm{L}^{-1}$, respectively), and for herbicides and biocides, they were measured for diuron and irgarol (33 and $2.5 \mathrm{ng} \mathrm{L}^{-1}$, respectively). Except for Diana lagoon, lagoons and semi-enclosed bays were the most contaminated areas for herbicides and pharmaceuticals, whilst, for alkylphenols, levels of contamination were similar in lagoons and coastal waters. This study demonstrates the relevance and utility of POCIS as quantitative tool for measuring low concentrations of emerging contaminants in marine waters.
\end{abstract}

Keywords : POCIS ; emerging contaminants ; hydrophilic contaminants ; marine monitoring ; Mediterranean sea 


\section{Introduction}

Currently, the level of chemical contamination in coastal waters -lato sensu- is incompletely known (Kümmerer, 2011). Lipophilic organic contaminants of historic concern such as organochlorine pesticides (OCs), polychlorinated biphenyls (PCBs) and polycyclic aromatic hydrocarbons (PAHs), have already been monitored for several decades within biomonitoring programmes, such as mussel watch (Goldberg, 1975, Andral et al., 2004). In contrast, levels of hydrophilic organic contaminants of emerging concern are not well documented in the marine environment, particularly in the Mediterranean Sea (Roose and Brinkman, 2005). In order to reduce the health risk that they pose, many new chemicals produced are more water-soluble. This means that they pass through wastewater treatment plants more easily and are released into the aquatic environment (Fenet et al., 2006), and finally, into the coastal marine environment (Alzieu and Romaña, 2006). So, pharmaceuticals, cosmetics and detergents are called emerging contaminants because of the recent improving of analytical and sampling techniques allowing their quantification at trace levels in natural waters, whereas these contaminants were already used and probably present in waters for a long time.

France is known as the leading consumer of psychotropic drugs in Europe (Briot, 2006) and the fourth largest user of pesticides in the world (Gatignol and Etienne, 2010). Nevertheless, on the French Mediterranean coast, which is among the most highly populated on the planet, knowledge of the levels of contamination due to emerging and usual hydrophilic contaminants is particularly scarce. Even if the EU Water Framework Directive (2000) requires Member States to assess the concentrations of priority substances in all coastal and transitional (estuaries, lagoons) water-bodies, at present, only few hydrophilic substances appear on priority substances lists (diuron, atrazine, simazine, isoproturon, alachlor, 4-nonylphenol and 4-tert-octylphenol), and no psychotropic drugs.

The likely presence on the French coast of emerging hydrophilic contaminants raises the question of their impact on organisms not initially targeted, which may be more sensitive and less well equipped than humans to eliminate or metabolize them. Also, to improve the assessment of the risks they pose in the marine environment, it is essential to improve the measurement of the concentrations of these emerging contaminants in coastal waters. This task is made difficult by the characteristics of the marine environment, a broad expanse whose dynamics are not easy to forecast, in which inputs become highly diluted and where chemicals are present in trace amounts, especially those in solution. Traditional sampling techniques using discrete water sampling are not well-suited to such characteristics: water volumes are too large to sample effectively, clean sampling techniques are expensive to use on boats, and due to the complex dynamics of the marine environment, there is a real problem of significance of a discrete sample. Also, only a few laboratories can reach the levels of sensitivity required for such water analysis.

Recently developed passive sampling techniques seem particularly well suited to the sampling of contaminants in aquatic environments (Stuer-Lauridsen, 2005; Vrana et al., 2005). One of these is POCIS (Polar Organic Contaminants Integrative Samplers) developed by scientists at the USGS Columbia Environmental Research Center (Petty et al., 2002) which can sample in an integrative way hydrophilic organic contaminants present at trace levels in natural waters. This is based on the assumption that levels of contaminants accumulated in POCIS represent a mean value, time and space integrated, of the ambient contamination of the surrounding waters. Higher concentrations, resulting from the accumulation of chemicals in POCIS exposed for long periods in water, make simpler the measurement of contaminant concentrations. Until now, POCIS has been used primarily for continental surface waters monitoring or around sewage discharges in order to screen for a wide range of chemical contaminants, such as pharmaceuticals, pesticides, alkylphenols or 
steroids (Alvarez et al., 2004; Jones-Lepp et al., 2004; Petty et al., 2004; Alvarez et al., 2005; Arditsoglou and Voutsa, 2008; Zhang et al., 2008; Li et al., 2010a). It is clear from these studies that POCIS could also be applied to monitoring studies in the marine environment (Harman et al., 2009a), although, to our knowledge, they have not yet been used in largescale marine water monitoring. The aim of our study was to investigate the utility of POCIS for sampling emerging contaminants present at trace levels in the coastal marine environment, and to undertake a first assessment of the significance of these contaminants on the French Mediterranean coast. In this work, we focused specifically on three groups of emerging and usual organic contaminants: pharmaceuticals, alkylphenols and pesticides, and in particular in the latter, herbicides and biocides.

\section{Materials and methods}

\subsection{Survey}

The study area was the French Mediterranean coast from the Italian border to the east to the Spanish border to the west (Fig. 1). In this area, usually named Gulf of Lion, the LiguroProvençal current is the main marine regional current flowing along the shelf break from the east to the west. River water input is dominated by the Rhône river, although several short coastal rivers can periodically, during major climatic events, locally also play a significant role.

Sampling sites were selected within the water-bodies defined under the EU Water Framework Directive (2000) for marine and transitional waters along the French Mediterranean coast (Fig.1). Table 1 gives the main characteristics and location of each sampling point.

Sampling was conducted during the dry summer season between June and August 2008, except for TRO and POR stations that were collected in September and December 2008, respectively. 21 pharmaceuticals, 6 alkylphenols, 26 pesticides and 1 biocide were investigated here using Polar Organic Contaminant Integrative Samplers (POCIS)(Alvarez et al., 2004) (Table 2). Thereafter, only detected compounds will be discussed.

Six POCIS per site were simultaneously deployed within a steel canister, one for pharmaceuticals, one for alkylphenols and four for herbicides and biocides analysis. The POCIS were tethered at half-depth in the water column, tied to a free rope connected with a surface buoy and a weight placed on the seabed. The exposure times varied between 14 and 28 days (respectively for THA and LAZ sampling points) (Table 1). The mean exposure time was 20 days. Temperature and salinity were measured twice, just before deployment and just after recovery of the samplers, with WTW field probes (Cond 1970i)(Table 1). At the end of the exposure period, each sampler was rinsed with ultrapure water, wrapped in aluminium foil and then in manila paper, and transported on ice to the laboratory. POCIS were then stored frozen $\left(-25^{\circ} \mathrm{C}\right)$ untill analysis.

\subsection{Materials and Chemicals}

Pharmaceutical and alkylphenol analytical standards were purchased from Sigma Aldrich (St Quentin Fallavier, France; purity > 98\%). Herbicide and biocide analytical standards were obtained from Cluzeau Info Labo (Ste-Foy-la-Grande, France; purity > $96 \%$ ). Deuterated herbicides and pharmaceuticals used as internal standards for quantification purposes were purchased from Euriso-Top (St. Aubin, France; purity > 98\%). Acetone, dichloromethane, ethyl acetate and methanol (HPLC reagent grade, Scharlau) were obtained from ICS (Belin- 
Beliet, France). Ultrapure deionised water was prepared using a Milli-Q system (Millipore, Molsheim, France). All POCIS used were purchased from Exposmeter AB (Tavelsjö, Sweden). These were of the pharmaceutical configuration, each filled with $200 \mathrm{mg}$ Oasis HLB sorbent, and had an exposure diameter of $54 \mathrm{~mm}$ and a sampling surface area of $45.8 \mathrm{~cm}^{2}$.

\subsection{POCIS extraction and analysis}

POCIS extraction and analysis procedures were as described and validated in Tapie et al. (2010). Briefly, $1 \mathrm{~h}$ before the start of the extraction procedure, POCIS were removed from the freezer and allowed to come to ambient temperature. The metal disks were dismantled and the membranes were detached from the disks. The sorbent was carefully transferred into an empty glass solid phase extraction (SPE) tube by rinsing it with ultrapure water. The sorbent was then dried under vacuum for $1 \mathrm{~h}$. Internal standards $\left(\mathrm{d}_{3}\right.$-naproxen, ketoprofen and ibuprofen, $d_{4}$-diclofenac, $d_{5}$-atrazine and terbuthylazine, $d_{6}$-diuron and gemfibrozil, $d_{10^{-}}$ simazine and $\mathrm{d}_{13}$-alachlor) were gravimetrically added and the sorbent was eluted successively using $10 \mathrm{~mL}$ of methanol, $10 \mathrm{~mL}$ of a methanol/dichloromethane mixture $(\mathrm{v} / \mathrm{v}$ : $50 / 50$ ), and finally $10 \mathrm{~mL}$ of dichloromethane. The extract was concentrated first by using a RapidVap vaccum evaporation system (Labconco, Kansas city, MO, USA) (Speed $70 \%$, heat $51^{\circ} \mathrm{C}$, vaccum $900 \mathrm{mbar}, 25 \mathrm{~min}$ ), then to dryness by a gentle stream of nitrogen and finally dissolved in $150 \mu \mathrm{L}$ of solvent required for analysis: in ethyl acetate for triazine and chloroacetanilide herbicides analysis by GC/MS; in methanol for phenylurea and sulfonylurea herbicides analysis by LC/MS/MS; in acetonitrile for pharmaceuticals analysis by LC/MS/MS (ESI-) (aspirin, ibuprofen, naproxen, gemfibrozil, ketoprofen and diclofenac); in a mixture of acetonitrile/water ( $\mathrm{v} / \mathrm{v}: \mathrm{80} / 20)$ for the other pharmaceuticals compounds analysed by LC/MS/MS (ESI+); and in methanol for alkylphenols analysis by LC/MS. The analytical procedures were adapted from Heath et al. (2010) for the pharmaceuticals, from Alder et al. (2006) for the pesticides and biocides analysis, from Cailleaud et al. (2007) for the alkylphenols, and all have been validated for use with POCIS extracts (Tapie et al., 2010). Analysed compounds were quantified using internal standard calibration. The response factors of the various compounds were determined by injection of a mixture of standard reference solutions. Procedural blanks were regularly performed during the sample extraction process and all the concentrations were blank-corrected. The performance of the analytical methods was monitored by the extraction of a spiked sample within each sample batch. The recoveries for the compounds determined ranged from 75 to $105 \%$ and the variability was less than $15 \%(n=3)$.

\subsection{Information given by POCIS}

The presence or absence of emerging contaminants collected using POCIS gives initial information regarding the contamination of coastal water-bodies, regardless of the duration and environmental conditions of exposure of the samplers. For contaminants which were detected, the quantification of the gross mass of each chemical sequestered will be expressed below as the concentration per POCIS in $\mathrm{ng} / \mathrm{g}$ of sorbent.

From these data, we can derive TWA concentrations (Time Weighted Average concentrations), that is to say, the average concentration of a contaminant present in the water sampled during the exposure period of the sampler. This allows a comparison between different sampling points. These TWA concentrations $(\mathrm{Cw}, \mathrm{ng} / \mathrm{L})$ are derived from the concentration of contaminant sequestered in POCIS (Cp, ng/g), and from the sampling rate (Rs, L/day/g) of each contaminant assessed during a laboratory calibration and are bound by the following equation:

$$
\mathrm{Cw}=\mathrm{Cp} \cdot \mathrm{Rs}^{-1} \cdot \mathrm{t}^{-1}
$$


Where t represents the exposure time (days) of the POCIS. These TWA concentrations allow to obtain a semi-quantitative information, essential to emphasize potential problems of pollution on watersheds and assess the associated risk for marine ecosystems. Performance Reference Compounds (PRC) were not used to correct the variability of the exposure. This choice will be discuss hereafter.

\section{Results and discussion}

Our results demonstrate for the first time that drug residues, alkylphenols, herbicides and biocides are present in all water-bodies of the French Mediterranean coast (Table 3). So, anthropogenic pressure is evident, even in marine water-bodies, and is clearly multifaceted. The presence of chemicals raises the question of their impact on organisms not initially targeted, chronically exposed to various mixtures of traces contaminants.

\subsection{Pharmaceuticals detected in lagoons and coastal waters}

Overall, 12 pharmaceuticals out of the 21 compounds screened for in this study were detected at trace levels (Table 3). Caffeine, a true tracer of anthropogenic inputs, was detected in all samples. Carbamazepine, theophylline, terbutaline and diazepam were also frequently detected, in 92, 92, 83 and $50 \%$ of water-bodies sampled, respectively. Seven pharmaceuticals (bromazepam, nordiazepam, fluoxetine, diclofenac, ketoprofen, salbutamol and gemfibrozil) were below $50 \%$ detection frequency. The last 9 pharmaceuticals monitored were not detected in any POCIS, and so are omitted from Table 3.

On average, six pharmaceuticals were detected in each water-body studied. The Berre lagoon (BER) was the site where the largest number of pharmaceuticals was detected (9 out of 21 determined), often also at the maximum concentrations. Indeed, all of the antidepressant drugs detected, as well as carbamazepine, an antiepileptic drug often used as antidepressant, showed the maximum concentrations in POCIS. Carbamazepine attained at BER site the highest concentration reported in POCIS during this survey $(487 \mathrm{ng} / \mathrm{g}$ of sorbent). The bay of Banyuls-sur-mer (SOL) and the site of Carry/le Rouet (ROU) gave the maximum concentrations for two anti-inflammatory drugs, ketoprofen and diclofenac (109 and $21 \mathrm{ng} / \mathrm{g}$ of sorbent, respectively). Finally, the bay of Lazaret (LAZ) gave the maximum levels of terbutaline and theophylline, two bronchodilators (36 and $4 \mathrm{ng} / \mathrm{g}$ sorbent, respectively).

\subsubsection{Methodology of choice of the sampling rates}

Several studies have reported sampling rates (Rs) for the accumulation of pharmaceuticals in POCIS (Alvarez et al., 2004; MacLeod et al., 2007; Togola and Budzinski, 2007; Martinez Bueno et al., 2009; Li et al., 2010a) (Table 4).

Alvarez et al. (2004) reported Rs significantly lower than other authors: 6-16-fold and 19-36fold lower for fluoxetine in flowing and quiescent conditions respectively, and 82-fold lower for omeprazole in flowing conditions (Table 4). These differences could be caused by POCIS surface area to sorbent ratio slightly lower $\left(180 \mathrm{~cm}^{2} / \mathrm{g}\right)$ for this latter (Table 4) and by differences in calibration design, probably due to aqueous dissipation processes of contaminants (MacLeod et al., 2007). Therefore, sampling rates for pharmaceuticals derived from Alvarez et al. (2004) will not be considered hereafter. The other authors used a quite similar POCIS configuration with a surface area to sorbent ratio in the range 200 to 230 
$\mathrm{cm}^{2} / \mathrm{g}$, similar to the one used herein. Li et al. (2010a, 2010b) recently reported that the sampling rates increased with temperature and flow, around a twofold increase between 5 and $25^{\circ} \mathrm{C}$ and around a threefold increase between flowing and quiescent conditions. In spite of this, these environmental parameters had a relatively minor influence on uptake of pharmaceuticals, with few exceptions, compared to their effects on sampling rates for the Semipermeable Membrane Devices (SPMDs) used to monitor non-polar contaminants. Togola and Budzinski (2007) reported also that there was no significant effect with the salinity on uptake rates, except for basic pharmaceuticals (fluoxetine, amitryptiline, doxepine and imipramine), for which uptakes rates decreased when salinity increased but in a relatively small range, ranging around a threefold factor.

Except for Alvarez et al. (2004), experimental design used by other authors to assess Rs values were slightly different, even if the range of environmental conditions tested were large, in particular for salinity (0 and 35), temperature (ranging $5-28^{\circ} \mathrm{C}$ ) and water flow conditions (quiescent and several flowing rates). Independently of experimental design and environmental conditions, the range of sampling rates obtained by these other authors for pharmaceuticals did not vary more than a threefold factor in flowing conditions, except for erythromycin (5.6-fold), ibuprofen (3.6-fold) and gemfibrozil (6.5-fold), and not more than a twofold factor in quiescent conditions, except for triclosan (4.1-fold) (Table 4). During field exposure of POCIS, up to one month, such variations of the environmental parameters are very unlikely to occur. So, sampling rates determined in the range of temperatures, salinities and flowing conditions of the field, can be considered close to "true" values of Rs and give realistic TWA concentrations without systematic use of a Performance Reference Compound (PRC). Moreover, erythromycin and triclosan were not studied here and ibuprofen was not detected. So, among compounds with a larger range of variation of Rs, gemfibrozil was the only pharmaceutical detected in our study.

Among available sampling rates for pharmaceuticals, those determined by Togola and Budzinski (2007) were assessed with environmental parameters close to those occurring in our field study, at $21^{\circ} \mathrm{C}$, for a salinity of 35 (PSU) and under flowing conditions. These Rs values are very close to those of $\mathrm{Li}$ et al. (2010a) and MacLeod et al. (2007) for all compounds except for gemfibrozil, which explains the greater range of variation of Rs obtained for this compound. For this chemical, the Rs derived from Togola and Budzinski (2007) increase the TWA concentration in comparison with previous authors, so special attention should be focused to the case of gemfibrozil. Despite this, the sampling rates of Togola and Budzinski (2007) were preferred to assess TWA concentrations, considering the local character of calibration experiments and the range of pharmaceuticals used in agreement with our study.

\subsubsection{TWA concentrations}

TWA concentrations in water (ng/L) have only been presented for compounds for which Rs values have previously been assessed (this excludes the theophylline), for which concentrations in water were calculated to be higher than $1 \mathrm{ng} / \mathrm{L}$, and/or for which the detection frequency was higher than $50 \%$ (Fig. 2).

Caffeine was detected in all coastal water-bodies at ambient average concentrations (or TWA concentrations) in the range 8-32 ng/L. Except for caffeine, the highest TWA concentrations were found for carbamazepine and gemfibrozil (respectively 12 and $5 \mathrm{ng} / \mathrm{L}$ ), both at the BER site. The only other significant TWA concentration found was for ketoprofen at the SOL site $(3.5 \mathrm{ng} / \mathrm{L})$. Other compounds were present at ultra-trace levels in water, at concentrations close to $1 \mathrm{ng} / \mathrm{L}$. The BER, THA and SOL sites were the sampling points at which the mean concentrations of pharmaceuticals were the most significant. These 
sampling sites are located in semi-enclosed water-bodies (lagoons or bays) with a longer water renewal time than coastal open waters and with very urbanized watersheds.

Pharmaceuticals have been detected only recently in the marine environment, there are few data in the literature and no Environmental Quality Standards (EQS) have been set for these compounds. Alzieu and Romaña (2006) have made a brief review of the available data. Two studies undertaken in the North Sea detected clofibric acid at a concentration of $7.8 \mathrm{ng} / \mathrm{L}$ (Buser et al., 1998) and caffeine at concentrations below $10 \mathrm{ng} / \mathrm{L}$ (Weigel, 2003). In comparison, these compounds can be found at high concentrations, up to the range of $\mu \mathrm{g} / \mathrm{L}$, in the effluents of wastewater treatment plants, both in continental surface waters (Ashton et al., 2004; Togola and Budzinski, 2008; Metcalfe et al., 2010; Unceta et al., 2010), and in marine coastal waters (Budzinski and Togola, 2006). Indeed, the latter reported ketoprofen and caffeine concentrations close to 6 and $8 \mu \mathrm{g} / \mathrm{L}$, respectively, at 300 meters from the outlet into the Mediterranean Sea of the sewage treatment plant of the city of Marseille (France), despite already high salinity. Data generated during our study indicated the presence of many drug residues in open and semi-closed marine waters, during a summer period. This period of study could explain the presence in waters of 3 bronchodilators, used more frequently during this season to fight against asthma. Conversely, levels of antidepressant and anti-inflammatory drugs might be more significant in autumn and winter during periods of greater prescription.

\subsection{Alkylphenols detected in lagoons and coastal waters}

On average, 5 alkylphenols were detected in each sample. In contrast with pharmaceuticals, all alkylphenols investigated were detected at least once (Table 3). Their detection frequency was also higher than for pharmaceuticals. Indeed, 4-nonylphenol (4-NP), 4-tert-octylphenol (4-OP) and 4-nonylphenol diethoxylate (NP2EO) were present in all of the coastal waterbodies studied. 4-nonylphenol monoethoxylate (NP1EO) and acetic nonylphenoxy acid (NP1EC) were present in 92 and 83\%, respectively, of coastal water-bodies sampled. Only bisphenol A (BPA) was rarely detected, in only five coastal water-bodies $(42 \%$ of the sampled water-bodies).

\subsubsection{Methodology of choice of the sampling rates}

In contrast to pharmaceuticals, strong differences in sampling rates are reported for alkylphenols between authors (Arditsoglou and Voutsa, 2008; Harman et al., 2008a; Zhang et al., 2008 and $\mathrm{Li}$ et al., 2010a). Sampling rates varied by a factor of 21 for 4 -nonylphenol and bisphenol $\mathrm{A}$ (Table 5).

These discrepancies are most probably due to differences in POCIS configuration, experimental designs and flow rates used in these studies, and highlight the need for a standardisation of POCIS making and calibrations. Li et al. (2010a) reported Rs significantly higher than other authors for alkylphenols, probably due to faster flowing conditions. Zhang et al. (2008) determined an Rs value for bisphenol A using a POCIS with a reduced ratio of surface area to sorbent (about one half: $115 \mathrm{~cm}^{2} / \mathrm{g}$ ) relative to other authors and to our study. Except for this latter, there is a real difficulty to discard Rs reported by previous authors even if these data were not consensual. In this context, the choice of Rs derived from Arditsoglou and Voutsa (2008) was made on the basis of temperature and above all on flowing conditions probably closer to those met in our field study than for other authors. In spite of this, the assessment of TWA concentrations for alkylphenols will be less precise than for pharmaceuticals, except for 4-OP for which the two Rs available were quite close (around a twofold factor only between authors), so conclusions will be moderate. 


\subsubsection{TWA concentrations}

The calculated TWA concentrations did not exceed $50 \mathrm{ng} / \mathrm{L}$ for any of the alkylphenol compounds (Fig. 3). The concentrations were similar to those reported in the literature for other coastal waters (David et al., 2009). The FOS, ANT, BER and LEU sites yielded the highest TWA concentrations (Fig. 3). Two of these sites, BER and FOS, are very confined sites (respectively, Berre lagoon and gulf of Fos). Both have a large watershed which is highly industrialized and urbanized. Conversely, the other two sites, ANT and LEU, are very open marine sites. The first one is located near a number of large cities (Antibes, Cannes, Nice), on the French "Riviera". This is also a highly urbanized area, with a high population in summer, which could explain the high levels of alkylphenols found at ANT. The second site, LEU, is located near the seaside resorts of Port Leucate and Port Barcarès in a less urbanized area. Many tourists are present at ANT and LEU sites during the summer period. Waste water treatment systems are often not adapted to this seasonal rising population, possibly causing the increase of alkylphenols output.

The two compounds mainly detected in water-bodies were 4-NP and NP1EO (respectively, in the range 2-33 and 5-41 ng/L with a maximum at FOS for the first and at ANT for the second). The comparison of TWA concentrations with Environmental Quality Standards (EQSs) for the marine environment (Table 6) shows that the concentrations of alkylphenols found in all water-bodies sampled during this survey are individually below their EQS levels. However, these are endocrine disrupting compounds (Fujimoto et al., 2002) that may have effects even at very low concentrations. The concentrations measured in our study were usually measured in highly diluted waters, distant from the shore, river mouths and direct sewage inputs. So, there are areas closer to the coast which will be exposed to higher concentrations, and likely to have a greater effect on aquatic animals. Likewise, the EQS are defined individually for each molecule, and even if none of alkylphenols detected in the survey exceeds these standards, the combined or even synergistic effects of alkylphenols or alkylphenols with other contaminants, may contribute to decrease the threshold of sensitivity of marine organisms.

\subsection{Herbicides and biocides detected in lagoons and coastal waters}

Overall, 15 herbicides and 1 biocide out of the 27 compounds determined in this study were detected at trace levels (Table 3 ). The detection frequencies were very variable from one pesticide to another: Diuron was the only pesticide detected in all samples. Terbuthylazine, atrazine, irgarol and simazine were detected respectively in $92,85,77$ and $77 \%$ of sampled water-bodies. The last two herbicides to be detected with a frequency greater than $50 \%$ were s-metolachlor and isoproturon (both with $69 \%$ ). Nine other herbicides were detected less frequently (from 8 to $46 \%$ ). The remaining eleven compounds are not reported in table 3 as they were never detected.

On average, 8 pesticides were detected in each water-body studied. The Berre lagoon (BER) was again the site where the most compounds were detected in water (13 out of 27 analysed). It was also the site where maximum concentrations were determined in the POCIS respectively for deisopropylatrazine, diuron, and s-metolachlor (242, 222 and 159 $\mathrm{ng} / \mathrm{g}$ of sorbent). The Thau lagoon (THA) and Carry/le Rouet (ROU) sites were also quite highly contaminated (10 pesticides detected at each). The THA site had high levels of diuron, terbuthylazine and irgarol (respectively, 204, 55 and $21 \mathrm{ng} / \mathrm{g}$ of sorbent). In contrast, the ROU site showed only concentrations below $50 \mathrm{ng} / \mathrm{g}$. Finally, the contamination at Lazaret bay site (LAZ) was also unusual. It exhibited significant quantities of diuron (137 ng/g of sorbent), the maximum concentrations for irgarol and propazine (respectively, 34 and 75 $\mathrm{ng} / \mathrm{g}$ of sorbent) and only 7 compounds determined. 


\subsubsection{Methodology of choice of the sampling rates}

Like for pharmaceuticals, Rs values for herbicides and biocides derived from Alvarez et al. (2004) were systematically below those of other authors: 2.5-fold lower for isoproturon relative to Mazzella et al. (2007), and twofold to 5.5-fold lower for diuron relative to Martínez Bueno et al. (2009) and Mazzella et al. (2007) respectively, in flowing conditions (Table 5). The reasons were probably the same that for pharmaceuticals but the less tendency for herbicides to aqueous dissipation during laboratory experiments could explain the relative small range of variation for Rs. Experimental design used by the two other authors were quite different: Mazzella et al. (2007) used a flow-through system while Martínez Bueno et al. (2009) used a static system stirred by magnetic bar. Nevertheless, the range of uptakes rates were similar for atrazine and simazine and below a threefold factor for diuron in flowing conditions. POCIS configuration and temperatures used in experimental designs were similar for the two studies. Except experimental design, only salinities were quite different between these authors and we finally favoured the one for which salinity were close to our field study. Therefore, TWA concentrations were calculated as above, using the Rs values determined by Martínez Bueno et al. (2009). Figure 4 shows the estimated concentrations in water expressed in $\mathrm{ng} / \mathrm{L}$. Only diuron, irgarol and atrazine are presented in this figure as they are the only molecules for which Rs values has been assessed by Martínez Bueno et al. (2009). These molecules showed occasionally significant concentrations in ambient waters (above $\mathrm{ng} / \mathrm{L}$ ). Other pesticides found in our study whose Rs values were determined, were only present at ultra-trace levels, at TWA concentrations close to $1 \mathrm{ng} / \mathrm{L}$ or lower.

\subsubsection{TWA concentrations}

TWA concentrations of pesticides detected in French Mediterranean coastal water-bodies are usually at trace levels. Overall, most confined sites (bays and lagoons) are clearly the most affected by herbicide and biocide contamination. The THA, BER and LAZ sites showed the highest pesticides concentrations in water, mainly due to diuron (respectively, with a TWA concentration of 33,26 and $11 \mathrm{ng} / \mathrm{L}$ ) and irgarol (respectively, with a TWA concentration of $2.5,0.5$ and $2.0 \mathrm{ng} / \mathrm{L}$ ). The THA and BER sites are coastal lagoons, with very long water renewal times and agricultural watersheds. The LAZ site is a semi-enclosed coastal bay with a highly urbanized watershed, and particularly intense shipping activity, including the presence of a naval arsenal. These activities include the use of anti-fouling paints and algaecides containing irgarol and probably diuron. The latter was prohibited in France for biocide use in april 2010. Except for irgarol, all compounds detected have an agricultural use. Amongst these, the marked presence of diuron is not surprising as it was a multi-use herbicide, used both in agriculture (especially in vineyards) and in urban areas, but also as a biocide in anti-fouling paints. It's still one of the most frequently detected compounds, with a detection frequency of $60 \%$ in samples downstream of large rivers in south eastern France, and a detection frequency of about $40 \%$ in the surface waters of the French Mediterranean watershed during monitoring conducted in 2002-2003 (AERMC, 2004).

Contamination may be higher during other periods of the year, in particular because of the seasonality of uses in watersheds (pesticides are mainly used in spring or autumn) and of rainfall events. TWA concentrations reported here for these compounds are clearly below the EQS defined for the marine environment (Table 6). This indicates that these compounds should not be individually toxic to marine ecosystems (EU Water Framework Directive, 2000). However, our study shows that $70 \%$ of water-bodies sampled are contaminated by more than 16 hydrophilic organic chemicals, including pesticides, and $38 \%$ by more than 20 . Among these chemicals, lots have not an individual EQS. The complex question of potentially additive or synergistic effects of mixtures of trace contaminants is currently not 
taken into account by the EU Water Framework Directive (Chèvre et al., 2008) and it is therefore not possible to currently assess such effects.

The literature data for marine water contamination by herbicides and biocides are scarce compared to inland waters. Because of the difficulties of undertaking trace analysis in marine waters, most studies have so far been focused downstream of large rivers in the Mediterranean Sea (Readman et al. 1993; Gómez-Gutiérrez et al., 2006; Comoretto et al., 2007), Atlantic ocean (Munaron et al., 2006), North sea (Steen et al., 2001, 2002), or in harbour areas in France (Tolosa et al., 1996), Germany (Lamoree et al., 2002), Japan (Okamura et al., 2003) and Bermuda (Connelly et al., 2001), because concentrations are generally higher by a factor of $10^{1}-10^{3}$. This latter study reported irgarol concentrations up to $10 \mathrm{ng} / \mathrm{L}$ at its marine reference site, slightly higher than the concentrations found in our study. Similarly, Carafa et al. (2006) showed that, in coastal lagoon of Sacca di Goro (Italy), the summer levels of diuron, atrazine, and simazine were generally below $10 \mathrm{ng} / \mathrm{L}$. This is in agreement with TWA concentrations assessed for the Thau and Berre lagoons, the two coastal lagoons studied here. Conversely, concentrations of terbuthylazine were ten-fold higher in Sacca di Goro waters, reflecting a more intense wineyard activity and use of pesticides within its watershed. All these studies were carried out using discrete water sampling techniques. In contrast, Shaw et al. (2010) were among the first to our knowledge to use passive samplers (chemcatchers and smpd) to assess pesticide concentrations in the waters of the Great Barrier Reef, Australia. These authors reported very low levels of herbicides at their marine reference site, within the range of those found in our study for diuron, simazine and atrazine (respectively 6, 2 and $1 \mathrm{ng} / \mathrm{L}$ ).

\subsection{Intercalibration of POCIS : a major challenge}

Our results have shown, for the first time in Mediterranean coastal waters, the presence of emerging contaminants such as pharmaceuticals and alkylphenols and more conventional contaminants such as hydrophilic pesticides. This suggests widespread contamination of French coastal waters. These compounds may have been undetected if "classic" sampling techniques had been used. With the use of the POCIS passive sampler and its capability for in situ pre-concentration, it is now possible to quantify trace contaminants (up to several tenths of $\mathrm{ng} / \mathrm{L}$ after an exposure of twenty days) in offshore waters. This should contribute to improve the knowledge of the contamination of coastal waters, and the support to local policy in survey, risk assessment and characterization of pollution sources on the watersheds. With the implementation of the EU Water Framework Directive (2000), countries are looking for reliable tools that can be used at European level for reporting the status of transitional and coastal water bodies, at reasonable cost. Our study demonstrates that POCIS are suitable tools for the determination of a range of hydrophilic organic contaminants. This study has allowed an ad hoc comparison of the various sampling sites during the 2008 summer season (a sort of snapshot of contamination at one time) but it still requires to be repeated to demonstrate the seasonal, persistent or exceptional character of contamination at the different sites.

The use of POCIS, however, must still be further developed, and can now present some comments and criticisms. The relatively large standard deviations observed across the different POCIS replicates used for pesticide analysis indicates the need to use these samplers as replicates, because they are probably not all exposed in a similar way for the same sample. The positionning of POCIS in field canister should be an area for further investigation. Exposure of each sampler in a canister should be harmonized relative to water flow. The PRC approach previously developed for SPMDs, and recently applied with success by Mazzella et al. $(2007,2008)$ to correct the uptakes of some herbicides in POCIS, could be usefull to adjust uptakes rates to exposure and minimize their variability. In the future, the 
cost to benefit ratio of this technique should be clarified for researchers but also for managers. Because recent studies showed the relatively minor effects of environmental conditions on uptake rates of contaminants sampled with POCIS: for salinity (Togola and Budzinski, 2007), for fouling (Harman et al., 2009b) and for water flow and temperature (Li et al., 2010a, 2010b). Our review of calibration data for contaminants (Tables 4 and 5) showed the great disparities that exist between the methods of calibration for POCIS. To make these data more widely exploitable by the scientific community and / or managers, it is essential that: i) the POCIS used around the world are tuned so that results can be compared, as it is clear that the sorbent surface exchange area can significantly influence the Rs values; ii) experimental calibration conditions are standardized so as to more easily compare, validate and use results. Large differences between the experimental conditions used (water renewal, temperature, exposure time, type of water used ...) may also lead to large variations in the Rs values obtained. The example of omeprazole is striking, as its Rs value may range between 0.03 (Alvarez et al., 2004) and 2.46 L/day (MacLeod et al., 2007) (Table 4). Until now, several authors studied the Rs calibration with various POCIS experimental designs, generally considering each environmental variable individually (temperature or salinity or water flow) (Tables 4 and 5). Nevertheless, the effect of the interaction of two environmental variables should be greater than the effect of each variable taken individually. So, the range of variation of Rs should be greater than this currently assessed for POCIS, and used herein. This hypothesis should be an area for further investigation. Finally, it is essential for the future to highlight the real capacities of POCIS to sample polar and semipolar contaminants, as recently reported by Harman et al. (2008b) for alkylated phenols and lindane.

\section{Conclusion}

In this study, dissolved emerging organic contaminants were detected for the first time in French Mediterranean coastal waters. These waters showed a large range of contamination, in agreement with the range of activities within their watersheds (agriculture, urban areas, seaside resorts and industrial areas). Water-bodies with long water renewal times, like coastal lagoons and semi-enclosed bays, showed the highest contamination levels, both for the number of contaminants detected and their ambient concentrations. Because of the importance of dilution processes, contamination levels were overall low. In spite of this, pharmaceuticals, alkylphenols, herbicides and a biocide were quantified in marine waters using to POCIS. These passive samplers represent a sensitive and promising tool for use in marine and coastal monitoring under the EU Water Framework Directive (2000) and the future EU Marine Strategy Framework Directive. Indeed, information is needed about marine contamination and POCIS could clearly help to better characterize the real exposure of marine organisms to complex mixtures of contaminants present at low concentrations. Finally, the lack of knowledge about chronical effects of low concentrations of mixtures of contaminants to marine organisms is still a topical question and should be investigated further in the future.

\section{Acknowledgments}

We wish to thank the Corsica-Mediterranean-Rhône Water Agency (Agence de l'Eau Rhône Méditerranée Corse) for its funding assistance and its partnership, the Coastal Waters Quality Offices (CQEL 06, 13, 34, 66 and 83), ADENA Bagnas, Observatory of Banyuls and GIPREB for their field support, without which this work would have been impossible. We should also like to thank the staff of the Ifremer coastal laboratories in Sète, Toulon, and Corsica for their valuable assistance with sample preparation and for logistics aspects. 


\section{References}

Alder, L., Greulich, K., Kempe, G., Vieth, B., 2006. Residue analysis of 500 high priority pesticides: better by GC-MS or LC-MS/MS? Mass Spectrometry Reviews, 25, 838865.

AERMC, 2004. Pesticides dans les eaux superficielles et souterraines des bassins RhôneMéditerranée et de la Corse. Données 2002 et 2003. Rapport de l'Agence de l'Eau Rhône Méditerranée \& Corse/Report of the French Mediterranean Water Agency, 48p.

Alvarez, D. A., Petty, J. D., Huckins, J. N., Jones-Lepp, T. L., Getting, D. T., Goddard, J. P., Manahan, S. E., 2004. Development of a passive, in situ, integrative sampler for hydrophilic organic contaminants in aquatic environments. Environmental Toxicology and Chemistry, 23 (7), 1640-1648.

Alvarez, D. A., Stackelberg, P. E., Petty, J. D., Huckins, J. N., Furlong, E. T., Zaugg, S. D., Meyer, M. T., 2005. Comparison of a novel passive sampler to standard watercolumn sampling for organic contaminants associated with wastewater effluents entering a New Jersey stream. Chemosphere, 61 (5), 610-622.

Alzieu, C., Romaña, L. A., 2006. Les médicaments, nouveaux contaminants de l'environnement marin? Environnement, Risques \& Santé, 5 (4), 320-324.

Andral, B., Stanisiere, J. Y., Sauzade, D., Damier, E., Thebault, H., Galgani, F., Boissery, P., 2004. Monitoring chemical contamination levels in the Mediterranean based on the use of mussel caging. Marine Pollution Bulletin, 49 (9-10), 704-712.

Arditsoglou, A., Voutsa, D., 2008. Passive sampling of selected endocrine disrupting compounds using polar organic chemical integrative samplers. Environmental Pollution, 156 (2), 316-324.

Ashton, D., Hilton, M., Thomas, K. V., 2004. Investigating the environmental transport of human pharmaceuticals to streams in the United Kingdom. Science of The Total Environment, 333 167-184.

Briot, M., 2006. Le bon usage des medicaments psychotropes. Report of the French Parliamentary Office for the assessment of Health Policies, Senate $n^{\circ} 422,21$ June 2006, 500p. http://www.assemblee-nationale.fr/12/pdf/rap-off/i3187.pdf

Budzinski, H., Togola, A., 2006. Présence de résidus de médicaments dans les différents compartiments du milieu aquatique. Environnement, Risques \& Santé, 5 (4), 248-253.

Buser, H.-R., Muller, M. D., Theobald, N., 1998. Occurrence of the pharmaceutical drug clofibric acid and the herbicide mecoprop in various Swiss lakes and in the North Sea. Environmental Science \& Technology, 32 (1), 188-192.

Cailleaud, K., Forget-Leray, J., Souissi, S., Lardy, S., Augagneur, S., Budzinski, H., 2007. Seasonal variations of hydrophobic organic contaminant concentrations in the watercolumn of the Seine Estuary and their transfer to a planktonic species Eurytemora affinis (Calanoïd, copepod). Part2 : Alkylphenols polyethoxylates. Chemosphere, 70, 281-287.

Carafa, R., Marinov, D., Dueri, S., Wollgast, J., Ligthart, J., Canuti, E., Viaroli, P., Zaldívar, J. M., 2006. A 3D hydrodynamic fate and transport model for herbicides in Sacca di Goro coastal lagoon (Northern Adriatic). Marine Pollution Bulletin, 52 (10), 12311248.

Chèvre, N., Maillard, E., Loepfe, C., Becker-van Slooten, K., 2008. Determination of water quality standards for chemical mixtures: Extension of a methodology developed for herbicides to a group of insecticides and a group of pharmaceuticals. Ecotoxicology and Environmental Safety, 71 (3), 740-748.

Comoretto, L., Arfib, B., Chiron, S., 2007. Pesticides in the Rhône river delta (France): Basic data for a field-based exposure assessment. Science of The Total Environment, 380 (1-3), 124-132.

Connelly, D. P., Readman, J. W., Knap, A. H., Davies, J., 2001. Contamination of the coastal waters of Bermuda by organotins and the triazine herbicide irgarol 1051. Marine Pollution Bulletin, 42 (5), 409-414. 
David, A., Fenet, H., Gomez, E., 2009. Alkylphenols in marine environments: Distribution monitoring strategies and detection considerations. Marine Pollution Bulletin, 58 (7), 953-960.

EU Water Framework Directive, 2000. Directive 2000/60/EC of the European Parliament and of the Council of 23 October 2000 establishing a framework for the Community action in the field of water policy. URL:http:/ec.europa.eu/environment/water/waterframework/index en.html.

Fenet, H., Gomez, E., Leclerc, M., Casellas, C., 2006. Devenir des médicaments dans l'environnement. Environnement, Risques \& Santé, Vol 5 (4), 243-247.

Fujimoto, Y., Sakuma, S., Inoue, T., Uno, E., Fujita, T., 2002. The endocrine disruptor nonylphenol preferentially blocks cyclooxygenase-1. Life Sciences, 70 (19), 22092214.

Gatignol, C., Etienne, J.-C., 2010. Pesticides et Santé. Report of the French Parliamentary Office for the assessment of Scientific and Technological choices, Senate $n^{\circ} 421,29$ April 2010, 262p. http://www.assemblee-nationale.fr/13/pdf/rap-off/i2463.pdf

Goldberg, E. D., 1975. The mussel watch -- A first step in global marine monitoring. Marine Pollution Bulletin, 6 (7), 111.

Gómez-Gutiérrez, A. I., Jover, E., Bodineau, L., Albaigés, J., Bayona, J. M., 2006. Organic contaminant loads into the Western Mediterranean Sea: Estimate of Ebro River inputs. Chemosphere, 65 (2), 224-236.

Harman, C., Tollefsen, K.E., Boyum, O., Thomas, K., Grung, M., 2008a. Uptake rates of alkylphenols, PAHs and carbazoles in semipermeable membrane devices (SPMDs) and polar organic chemical integrative samplers (POCIS). Chemosphere, 72, 15101516.

Harman, C., Boyum, O., Tollefsen, K.E., Thomas, K.V., Grung, M., 2008b. Uptake of some selected aquatic pollutants in semipermeable membrane devices (SPMDs) and the polar organic chemical integrative samplers (POCIS). Journal of Environmental Monitoring, 10, 239-247.

Harman, C., Thomas, K.V., Tollefsen, K.E., Meier, S., Boyum, O., Grung, M., 2009a. Monitoring the freely dissolved concentrations of polycyclic aromatic hydrocarbons (PAH) and alkylphenols (AP) around a Norwegian oil platform by holistic passive sampling. Marine Pollution Bulletin, 58, 1671-1679.

Harman, C., Boyum, O., Thomas, K.V., Grung, M., 2009b. Small but different effect of fouling on the uptake rates of semipermeable membrane devices and polar organic chemical integrative samplers. Environmental Toxicology and Chemistry, 28 (11), 2324-2332.

Heath, E., Kosjek, T., Farre, M., Quintana, J.B., de Alencastro, L.F., Castiglioni, S., Gans, O., Langford, K., Loos, R., Radjenovi, J., Mainero Rocca, L., Budzinski, H., Tsipi, D., Petrovic, M., Barcelo, D., 2010. Second interlaboratory exercise on non-steroidal antiinflammatory drug analysis in environmental aqueous samples. Talanta, 81, 11891196.

Jones-Lepp, T. L., Alvarez, D. A., Petty, J. D., Huckins, J. N., 2004. Polar organic chemical integrative sampling and liquid chromatography-electrospray/ion-trap mass spectrometry for assessing selected prescription and illicit drugs in treated sewage effluents. Archives of Environmental Contamination and Toxicology, 47 (4), 427-439.

Kümmerer, K., 2011. Emerging Contaminants. In: Treatise on Water Science, Chapter 3.04. Elsevier, Oxford, pp. 69-87.

Lamoree, M. H., Swart, C. P., Van der Horst, A., Van Hattum, B., 2002. Determination of diuron and the antifouling paint biocide irgarol 1051 in Dutch marinas and coastal waters. Journal of Chromatography A, 970 (1-2), 183-190.

Li, H., Helm, P.A., Metcalfe, C.D., 2010a. Sampling in the great lakes for pharmaceuticals, personal care products, and endocrine-disrupting substances using the passive polar organic chemical integrative sampler. Environmental Toxicology and Chemistry, 29 (4), 751-762. 
Li, H., Vermeirssen, E.L.M., Helm, P.A., Metcalfe, C.D., 2010b. Controlled field evaluation of water flow rate effects on sampling polar organic compounds using polar organic chemical integrative samplers. Environmental Toxicology and Chemistry, 29 (11), 2461-2469.

MacLeod, S. L., McClure, E. L., Wong, C. S., 2007. Laboratory calibration and field deployment of the Polar organic chemical integrative sampler for pharmaceuticals and personal care products in wastewater and surface water. Environmental Toxicology and Chemistry, 26 (12), 2517-2529.

Martínez Bueno, M. J., Hernando, M. D., Agüera, A., Fernández-Alba, A. R., 2009. Application of passive sampling devices for screening of micro-pollutants in marine aquaculture using LC-MS/MS. Talanta, 77 (4), 1518-1527.

Mazzella, N., Dubernet, J.-F., Delmas, F., 2007. Determination of kinetic and equilibrium regimes in the operation of polar organic chemical integrative samplers: Application to the passive sampling of the polar herbicides in aquatic environments. Journal of Chromatography A, 1154 (1-2), 42-51.

Mazzella, N., Debenest, T., Delmas, F., 2008. Comparison between the polar organic chemical integrative sampler and the solid-phase extraction for estimating herbicide time-weighted average concentrations during a microcosm experiment. Chemosphere, 73 (4), 545-550.

Metcalfe, C. D., Chu, S., Judt, C., Li, H., Oakes, K. D., Servos, M. R., Andrews, D. M., 2010. Antidepressants and their metabolites in municipal wastewater, and downstream exposure in an urban watershed. Environmental Toxicology and Chemistry, 29 (1), 79-89.

Munaron, D., Dubernet, J. F., Delmas, F., Stanisiere, J. Y., Scribe, P., 2006. Assessment of the quantities of herbicides and nutrients brought down by the river Charente to the coast and modelling of the dispersion of atrazine in the Marennes-Oleron bay. Cahiers de Biologie Marine, 47 (1), 85-92.

Okamura, H., Aoyama, I., Ono, Y., Nishida, T., 2003. Antifouling herbicides in the coastal waters of western Japan. Marine Pollution Bulletin, 47 (1-6), 59-67.

Petty, J. D., Huckins, J. N., Alvarez, D. A., 2002. Device for sequestration and concentration of polar organic chemicals from water. US Patent, 6,478,961 November 12, 2002.

Petty, J. D., Huckins, J. N., Alvarez, D. A., Brumbaugh, W. G., Cranor, W. L., Gale, R. W., Rastall, A. C., Jones-Lepp, T. L., Leiker, T. J., Rostad, C. E., Furlong, E. T., 2004. A holistic passive integrative sampling approach for assessing the presence and potential impacts of waterborne environmental contaminants. Chemosphere, 54 (6), 695-705.

Readman, J. W., Albanis, T. A., Barcelo, D., Galassi, S., Tronczynski, J., Gabrielides, G. P., 1993. Herbicide contamination of Mediterranean estuarine waters: Results from a MED POL pilot survey. Marine Pollution Bulletin, 26 (11), 613-619.

Roose, P., Brinkman, U.A.Th., 2005. Monitoring organic microcontaminants in the marine environment: principles, programmes and progress. Trends in Analytical Chemistry, 24 (11), 897-926.

Shaw, M., Furnas, M. J., Fabricius, K., Haynes, D., Carter, S., Eaglesham, G., Mueller, J. F., 2010. Monitoring pesticides in the Great Barrier Reef. Marine Pollution Bulletin, 60 (1), 113-122.

Steen, R. J. C. A., Van der Vaart, J., Hiep, M., Van Hattum, B., Cofino, W. P., Brinkman, U. A. T., 2001. Gross fluxes and estuarine behaviour of pesticides in the Scheldt Estuary (1995-1997). Environmental Pollution, 115 (1), 65-79.

Steen, R. J. C. A., Evers, E. H. G., Van Hattum, B., Cofino, W. P., Brinkman, U. A. T., 2002. Net fluxes of pesticides from the Scheldt Estuary into the North Sea: a model approach. Environmental Pollution, 116 (1), 75-84.

Stuer-Lauridsen, F., 2005. Review of passive accumulation devices for monitoring organic micropollutants in the aquatic environment. Environmental Pollution, 136 (3), 503524. 
Tapie, N., Devier, M.H., Soulier, C., Creusot, N., Le Menach, K., Aït-Aïssa, S., Vrana, B., Budzinski H., 2011. Passive samplers for chemical substance monitoring and associated toxicity assessment in water. Water Science and Technology 63 (10), 2418-2426.

Togola, A., Budzinski, H., 2007. Development of polar organic integrative samplers for analysis of pharmaceuticals in aquatic systems. Analytical Chemistry, 79 (17), 67346741.

Togola, A., Budzinski, H., 2008. Multi-residue analysis of pharmaceutical compounds in aqueous samples. Journal of Chromatography A, 1177 (1), 150-158.

Tolosa, I., Readman, J. W., Blaevoet, A., Ghilini, S., Bartocci, J., Horvat, M., 1996. Contamination of Mediterranean (Côte d'Azur) coastal waters by organotins and irgarol 1051 used in antifouling paints. Marine Pollution Bulletin, 32 (4), 335-341.

Unceta, N., Sampedro, M. C., Bakar, N. K. A., Gómez-Caballero, A., Goicolea, M. A., Barrio, R. J., 2010. Multi-residue analysis of pharmaceutical compounds in wastewaters by dual solid-phase microextraction coupled to liquid chromatography electrospray ionization ion trap mass spectrometry. Journal of Chromatography A, 1217 (20), 3392-3399.

Vrana, B., Allan, I. J., Greenwood, R., Mills, G. A., Dominiak, E., Svensson, K., Knutsson, J., Morrison, G., 2005. Passive sampling techniques for monitoring pollutants in water. Trends in Analytical Chemistry, 24 (10), 845-868.

Weigel, S., 2003. Occurrence, distribution and fate of pharmaceuticals and further polar contaminants in the marine environment. PhD Thesis, University of Hamburg, Deutschland, 136p.

Zhang, Z., Hibberd, A., Zhou, J. L., 2008. Analysis of emerging contaminants in sewage effluent and river water: Comparison between spot and passive sampling. Analytica Chimica Acta, 607 (1), 37-44.

\section{Tables}

Table 1 : Hydrological and morphological characteristics of sampling sites, and periods of exposure of POCIS in marine waters.

\begin{tabular}{|c|c|c|c|c|c|c|c|c|c|}
\hline $\begin{array}{l}\text { Sampling } \\
\text { Point }\end{array}$ & Description & $\begin{array}{l}\text { Depth } \\
\text { Site }\end{array}$ & $\begin{array}{l}\text { Depth of } \\
\text { POCIS }\end{array}$ & Temp.* & Salinity* & Exposure Date & $\begin{array}{l}\text { Exposure } \\
\text { time }\end{array}$ & Latitude & Longitude \\
\hline & & (m) & (m) & $\left({ }^{\circ} \mathrm{C}\right)$ & (PSU) & & (d) & (dmd w84) & (dmd w84) \\
\hline SOL & Semi-closed bay & 26 & 24 & 15.7 & 38.0 & 23/06/08 16:05 & 21.8 & $42^{\circ} 29.308 \mathrm{~N}$ & $03^{\circ} 08.599 \mathrm{E}$ \\
\hline LEU & Coastal water & 8 & 3 & 21.0 & 38.2 & 15/07/08 11:30 & 20.0 & $42^{\circ} 52.892 \mathrm{~N}$ & $03^{\circ} 03.540 \mathrm{E}$ \\
\hline AGD & Coastal water & 12 & 6 & 19.9 & 37.5 & 01/07/08 10:15 & 17.0 & $43^{\circ} 15.048 \mathrm{~N}$ & $03^{\circ} 30.011 \mathrm{E}$ \\
\hline THA & Lagoon & 2 & 1 & 23.9 & 37.4 & 18/06/08 09:20 & 14.3 & $43^{\circ} 27.130 \mathrm{~N}$ & $03^{\circ} 40.379 \mathrm{E}$ \\
\hline FOS & Semi-closed bay & 20 & 10 & 18.1 & 38.9 & $24 / 06 / 0816: 35$ & 20.7 & $43^{\circ} 23.201 \mathrm{~N}$ & $04^{\circ} 56.479 \mathrm{E}$ \\
\hline BER & Lagoon & 9 & 4 & 22.4 & 26.7 & 20/06/08 10:35 & 20.1 & $43^{\circ} 26.529 \mathrm{~N}$ & $05^{\circ} 05.845 \mathrm{E}$ \\
\hline $\mathrm{ROU}$ & Coastal water & 14 & 6 & 17.6 & 39.0 & $24 / 06 / 08 \quad 10: 45$ & 21.2 & $43^{\circ} 19.580 \mathrm{~N}$ & $05^{\circ} 10.232 \mathrm{E}$ \\
\hline PLA & Coastal water & 25 & 12 & 17.7 & 39.2 & 25/06/08 12:05 & 27.9 & $43^{\circ} 11.310 \mathrm{~N}$ & $05^{\circ} 22.721 \mathrm{E}$ \\
\hline LAZ & Semi-closed bay & 4 & 2 & 20.8 & 37.9 & 23/06/08 09:40 & 28.0 & $43^{\circ} 05.176 \mathrm{~N}$ & $05^{\circ} 54.387 \mathrm{E}$ \\
\hline POR & Coastal water & 37 & 16 & 13.8 & - & 02/12/08 11:15 & 20.0 & $43^{\circ} 00.986 \mathrm{~N}$ & $06^{\circ} 21.372 \mathrm{E}$ \\
\hline TRO & Coastal water & 31 & 16 & 22.1 & 38.5 & 01/09/08 12:15 & 18.0 & $43^{\circ} 16.543 \mathrm{~N}$ & $06^{\circ} 42.208 \mathrm{E}$ \\
\hline ANT & Coastal water & 15 & 10 & 20.6 & 37.3 & 24/06/08 08:40 & 15.0 & $43^{\circ} 32.688 \mathrm{~N}$ & $07^{\circ} 07.716 \mathrm{E}$ \\
\hline DIA & Lagoon & 11 & 5 & 26.6 & 37.5 & 30/06/08 11:40 & 20.9 & $42^{\circ} 07.665 \mathrm{~N}$ & $09^{\circ} 31.716 \mathrm{E}$ \\
\hline
\end{tabular}

* : Mean of 2 measures realized at exposure and removal dates

- : Not measured 
Table 2 : Chemicals investigated in this study.

\begin{tabular}{|c|c|c|c|}
\hline Class & Chemicals & Use & CAS Number \\
\hline Alk. & 4-nonylphenol (4-NP) & Non ionic detergent metabolite & $104-40-5$ \\
\hline Alk. & 4-nonylphenol diethoxylate (NP2EO) & Non ionic detergent metabolite & $20427-84-3$ \\
\hline Alk. & 4-nonylphenol mono-ethoxylate (NP1EO) & Non ionic detergent metabolite & $104-35-8$ \\
\hline Alk. & 4-tert-octylphenol (4-OP) & Non ionic detergent metabolite & $140-66-9$ \\
\hline Alk. & Acetic nonylphenoxy acid (NP1EC) & Non ionic detergent metabolite & $3115-49-9$ \\
\hline Alk. & Bisphenol A (BPA) & Plasticizer & 80-05-7 \\
\hline Biocide & Irgarol & Biocide in antifouling paints & $28159-98-0$ \\
\hline Pest. & 3,4-dichlorophenylurea (DPU) & Herbicide metabolite & $2327-02-8$ \\
\hline Pest. & 3,4-dichlorophenylmethylurea (DPMU) & Herbicide metabolite & $3567-62-2$ \\
\hline Pest. & Acetochlor & Herbicide & $34256-82-1$ \\
\hline Pest. & Alachlor & Herbicide & $15972-60-8$ \\
\hline Pest. & Atrazine & Herbicide & 1912-24-9 \\
\hline Pest. & Chlorotoluron & Herbicide & $15545-48-9$ \\
\hline Pest. & Chlorsulfuron & Herbicide & $64902-72-3$ \\
\hline Pest. & Cyanazine & Herbicide & $21725-46-2$ \\
\hline Pest. & Cyromazine & Insecticide & $66215-27-8$ \\
\hline Pest. & Desethylatrazine (DEA) & Herbicide metabolite & $6190-65-4$ \\
\hline Pest. & Deisopropylatrazine (DIA) & Herbicide metabolite & $1007-28-9$ \\
\hline Pest. & Dimethachlor & Herbicide & $50563-36-5$ \\
\hline Pest. & Diuron & Herbicide & $330-54-1$ \\
\hline Pest. & Isoproturon & Herbicide & $34123-59-6$ \\
\hline Pest. & Linuron & Herbicide & $330-55-2$ \\
\hline Pest. & Metazachlor & Herbicide & $67129-08-2$ \\
\hline Pest. & Metoxuron & Herbicide & $19937-59-8$ \\
\hline Pest. & Nicosulfuron & Herbicide & 111991-09-4 \\
\hline Pest. & Prometryn & Herbicide & 7287-19-6 \\
\hline Pest. & Propachlor & Herbicide & $1918-16-7$ \\
\hline Pest. & Propazine & Herbicide & $139-40-2$ \\
\hline Pest. & Pymetrozine & Insecticide & $123312-89-0$ \\
\hline Pest. & Simazine & Herbicide & 122-34-9 \\
\hline Pest. & S-Metolachlor & Herbicide & $87392-12-9(\mathrm{~S})$ \\
\hline Pest. & Terbuthylazine & Herbicide & $5915-41-3$ \\
\hline Pest. & Terbutryn & Herbicide & 886-50-0 \\
\hline Pharm. & Alprazolam & Anti-depressant & $28981-97-7$ \\
\hline Pharm. & Amitriptyline & Anti-depressant & $50-48-6$ \\
\hline Pharm. & Aspirin & Analgesic, anti-inflammatory & $50-78-2$ \\
\hline Pharm. & Bromazepam & Anti-depressant & $1812-30-2$ \\
\hline Pharm. & Caffeine & Stimulant & $58-08-2$ \\
\hline Pharm. & Carbamazepine & Anti-epileptic & 298-46-4 \\
\hline Pharm. & Clenbuterol & Bronchodilator & $37148-27-9$ \\
\hline Pharm. & Diazepam & Anti-depressant & 439-14-5 \\
\hline Pharm. & Diclofenac & Anti-inflammatory & $15307-86-5$ \\
\hline Pharm. & Doxepin & Anti-depressant & $1668-19-5$ \\
\hline Pharm. & Fluoxetine & Anti-depressant & $54910-89-3$ \\
\hline Pharm. & Gemfibrozil & To reduce lipid levels & $25812-30-0$ \\
\hline Pharm. & Ibuprofen & Antalgic & $15687-27-1$ \\
\hline Pharm. & Imipramine & Anti-depressant & $50-49-7$ \\
\hline Pharm. & Ketoprofen & Anti-inflammatory & $22071-15-4$ \\
\hline Pharm. & Naproxen & Anti-inflammatory & $22204-53-1$ \\
\hline Pharm. & Nordiazepam & Anti-depressant & $1088-11-5$ \\
\hline Pharm. & Paracetamol & Antalgic & $103-90-2$ \\
\hline Pharm. & Salbutamol & Bronchodilator & $18559-94-9$ \\
\hline Pharm. & Terbutaline & Bronchodilator & $23031-25-6$ \\
\hline Pharm. & Theophylline & Bronchodilator & $58-55-9$ \\
\hline
\end{tabular}


Table 3: Chemicals detected in French Mediterranean coastal waters and their concentrations in POCIS in $\mathrm{ng} / \mathrm{g}$ of sorbent. Compounds never detected were not reported here.

\begin{tabular}{|c|c|c|c|c|c|c|c|c|c|c|c|c|c|}
\hline Chemicals & SOL & LEU & AGD & THA & FOS & BER & ROU & PLA & LAZ & POR & TRO & ANT & DIA \\
\hline & $\mathrm{ng} / \mathrm{g}$ & $\mathrm{ng} / \mathrm{g}$ & $\mathrm{ng} / \mathrm{g}$ & $\mathrm{ng} / \mathrm{g}$ & $\mathrm{ng} / \mathrm{g}$ & $\mathrm{ng} / \mathrm{g}$ & $\mathrm{ng} / \mathrm{g}$ & $\mathrm{ng} / \mathrm{g}$ & $\mathrm{ng} / \mathrm{g}$ & $\mathrm{ng} / \mathrm{g}$ & $\mathrm{ng} / \mathrm{g}$ & $\mathrm{ng} / \mathrm{g}$ & $\mathrm{ng} / \mathrm{g}$ \\
\hline 4-NP & 29 & 97 & 41 & 75 & 393 & 241 & 73 & 129 & 150 & 195 & - & 170 & 91 \\
\hline $4-\mathrm{OP}$ & 20 & 191 & 14 & 9 & 131 & 50 & 77 & 17 & 32 & 15 & - & 45 & 14 \\
\hline BPA & 61 & 150 & 8 & nd & 65 & nd & nd & 48 & nd & nd & - & nd & nd \\
\hline NP1EC & 2 & 54 & 6 & 4 & 11 & nd & 35 & 2 & 1 & 2 & - & 14 & nd \\
\hline NP1EO & 50 & 72 & 37 & nd & 249 & 134 & 81 & 277 & 191 & 124 & - & 273 & 85 \\
\hline NP2EO & 39 & 16 & 22 & 15 & 99 & 36 & 17 & 37 & 41 & 24 & - & 35 & 21 \\
\hline Irgarol & 3 & 3 & 2 & 21 & 4 & 7 & 3 & 2 & 34 & nd & nd & 2 & nd \\
\hline Acetochlor & nd & nd & nd & nd & nd & nd & nd & nd & nd & 5 & nd & nd & nd \\
\hline Alachlor & nd & nd & nd & nd & nd & nd & nd & 2 & nd & nd & nd & nd & 5 \\
\hline Atrazine & 12 & 10 & 31 & 8 & 25 & 18 & 24 & 24 & 21 & nd & 8 & 10 & nd \\
\hline Chlorotoluron & nd & nd & 1 & 1 & 1 & 2 & 1 & 1 & nd & nd & nd & nd & nd \\
\hline DEA & nd & nd & 8 & nd & nd & 44 & 10 & nd & nd & nd & nd & nd & nd \\
\hline DIA & nd & nd & nd & nd & nd & 242 & nd & nd & nd & nd & nd & nd & nd \\
\hline Dimethachlor & nd & 12 & nd & nd & nd & nd & nd & nd & nd & nd & nd & nd & nd \\
\hline Diuron & 6 & 6 & 5 & 204 & 20 & 222 & 26 & 8 & 137 & 5 & 5 & 4 & 1 \\
\hline DPMU & nd & nd & nd & 6 & nd & 17 & nd & nd & nd & nd & nd & nd & 1 \\
\hline Isoproturon & 1 & 2 & 1 & 1 & 2 & 7 & 1 & 1 & 1 & nd & nd & nd & nd \\
\hline Propazine & nd & nd & nd & 24 & nd & 27 & 6 & nd & 75 & nd & 5 & nd & nd \\
\hline Simazine & 2 & 9 & 12 & 16 & 13 & 12 & 16 & 9 & 9 & nd & nd & nd & 1 \\
\hline S-Metolachlor & 11 & 17 & 31 & nd & 37 & 159 & 50 & 27 & 11 & nd & 3 & nd & nd \\
\hline Terbuthylazine & 19 & 13 & 13 & 55 & 23 & 40 & 15 & 15 & nd & 15 & 14 & 18 & 18 \\
\hline Terbutryn & nd & nd & nd & 10 & nd & 21 & nd & nd & nd & nd & nd & nd & nd \\
\hline Bromazepam & nd & nd & nd & nd & 1 & 8 & nd & nd & nd & nd & - & nd & nd \\
\hline Caffeine & 133 & 117 & 109 & 178 & 123 & 237 & 108 & 121 & 97 & 63 & - & 128 & 88 \\
\hline Carbamazepine & 5 & 11 & 10 & 45 & 9 & 487 & 5 & 3 & nd & 7 & - & 10 & 2 \\
\hline Diazepam & 4 & nd & 2 & nd & nd & 8 & nd & 4 & 8 & nd & - & 5 & nd \\
\hline Diclofenac & nd & nd & nd & 1 & 9 & nd & 21 & 2 & nd & nd & - & nd & nd \\
\hline Fluoxetine & nd & nd & nd & nd & nd & 1 & nd & nd & nd & nd & - & nd & nd \\
\hline Gemfibrozil & nd & nd & nd & nd & nd & 27 & nd & nd & nd & 1 & - & 2 & nd \\
\hline Ketoprofen & 109 & nd & nd & 12 & nd & nd & nd & nd & 31 & 23 & - & nd & 17 \\
\hline Nordiazepam & nd & nd & nd & nd & nd & 23 & 1 & nd & nd & 1 & - & nd & nd \\
\hline Salbutamol & 1 & nd & nd & nd & nd & nd & nd & nd & nd & nd & - & nd & nd \\
\hline Terbutaline & 1 & 1 & nd & 3 & 1 & 2 & nd & 2 & 4 & 2 & - & 1 & 2 \\
\hline Theophylline & nd & 13 & 10 & 26 & 9 & 35 & 10 & 23 & 36 & 16 & - & 7 & 17 \\
\hline
\end{tabular}

nd : not detected.

- : not monitored 
Table 4 : Review of experimental parameters reported during Rs calibration experiments of polar organic contaminant integrative samplers (POCIS) for pharmaceuticals (with pharmaceutical configuration of POCIS only).

\begin{tabular}{|c|c|c|c|c|c|c|c|c|c|}
\hline Chemicals & Water $^{\mathrm{a}}$ & $\begin{array}{l}\text { POCIS Surf. area } \\
\text { /mass of sorbent }\end{array}$ & $\begin{array}{l}\text { Experimental } \\
\text { design }\end{array}$ & Flowing conditions ${ }^{\mathrm{b}}$ & Temp. & Exposure & Rs Quiescent & Rs Flowing & Ref. \\
\hline & & $\left(\mathrm{cm}^{2} / \mathrm{g}\right)$ & & & $\left({ }^{\circ} \mathrm{C}\right)$ & (Day) & (L/day) & (L/day) & \\
\hline Amitriptiline & $\mathrm{U}$ and $\mathrm{S}$ & n.d. ${ }^{d}$ & 1 POCIS / 2 L & SBMB & 15 and 21 & 10 & - & $0.448^{\mathrm{c}}$ & Togola and budzinski, 2007 \\
\hline Atenolol & U & $200^{\mathrm{e}}$ & 1 POCIS / $3 \mathrm{~L}$ & SBMB (800-900 rpm) & 5,15 and $25^{\mathrm{f}}$ & 8 & 0.073 & $0.087-0.094$ & $\mathrm{Li}$ et al., 2010a \\
\hline Atenolol & $\mathrm{U}$ & 229 & 1 POCIS / $3 \mathrm{~L}$ & U\&SC & 22 and $28^{\mathrm{h}}$ & up to 29 & 0.037 & 0.04 & MacLeod et al., 2007 \\
\hline Azithromycin & n.d. & 180 & 1 POCIS / $1 \mathrm{~L}$ & $\mathrm{U} \& \mathrm{SC}$ & 23 and 27 & up to 56 & 0.021 & 0.12 & Alvarez et al., 2004 \\
\hline Caffeine & U & $200^{\mathrm{e}}$ & 1 POCIS / $3 \mathrm{~L}$ & SBMB (800-900 rpm) & 5,15 and $25^{\mathrm{f}}$ & 8 & n.d. & $0.096-0.151$ & Li et al., 2010a \\
\hline Caffeine & $\mathrm{U}$ and $\mathrm{S}$ & n.d. ${ }^{\text {d }}$ & 1 POCIS / 2 L & SBMB & 15 and 21 & 10 & - & $0.078^{\mathrm{c}}$ & Togola and budzinski, 2007 \\
\hline Carbamazepine & U & $200^{\mathrm{e}}$ & 1 POCIS / $3 \mathrm{~L}$ & SBMB (800-900 rpm) & 5,15 and $25^{\mathrm{f}}$ & 8 & 0.235 & $0.230-0.561$ & Li et al., 2010a \\
\hline Carbamazepine & $\mathrm{U}$ & 229 & 1 POCIS / $3 \mathrm{~L}$ & U\&SC & 22 and $28^{\mathrm{h}}$ & up to 29 & 0.112 & 0.348 & MacLeod et al., 2007 \\
\hline Carbamazepine & $\mathrm{U}$ and $\mathrm{S}$ & n.d. ${ }^{d}$ & 1 POCIS $/ 2 \mathrm{~L}$ & SBMB & 15 and 21 & 10 & -.112 & $0.398^{\mathrm{c}}$ & Togola and budzinski, 2007 \\
\hline Clarithromycin & U & 229 & 1 POCIS / $3 \mathrm{~L}$ & U\&SC & 22 and $28^{\mathrm{h}}$ & up to 29 & 0.09 & 0.668 & MacLeod et al., 2007 \\
\hline Diazepam & $\mathrm{U}$ and $\mathrm{S}$ & n.d. ${ }^{\mathrm{d}}$ & 1 POCIS / $2 \mathrm{~L}$ & SBMB & 15 and 21 & 10 & - & $0.28^{\mathrm{c}}$ & Togola and budzinski, 2007 \\
\hline Diclofenac & $\mathrm{U}$ and $\mathrm{S}$ & n.d. ${ }^{\mathrm{d}}$ & 1 POCIS / $2 \mathrm{~L}$ & SBMB & 15 and 21 & 10 & - & $0.166^{\mathrm{c}}$ & Togola and budzinski, 2007 \\
\hline Diclofenac & $\mathrm{U}$ & 229 & 1 POCIS / $3 \mathrm{~L}$ & $\mathrm{U} \& \mathrm{SC}$ & 22 and $28^{h}$ & up to 29 & 0.092 & 0.166 & MacLeod et al., 2007 \\
\hline Doxepine & $\mathrm{U}$ and $\mathrm{S}$ & n.d. ${ }^{d}$ & 1 POCIS / 2 L & SBMB & 15 and 21 & 10 & - & $0.536^{\mathrm{c}}$ & Togola and budzinski, 2007 \\
\hline Erythromycin & Artificial S & n.d. d $^{2}$ & 1 POCIS / 2 L & SBMB & 21 & 7 & - & 0.163 & Martinez Bueno et al., 2009 \\
\hline Erythromycin & $\mathrm{U}$ & 229 & 1 POCIS / $3 \mathrm{~L}$ & U\&SC & 22 and $28^{\mathrm{h}}$ & up to 29 & 0.183 & 0.911 & MacLeod et al., 2007 \\
\hline Fluoxetine & n.d. & 180 & $1 \mathrm{POCIS} / 1 \mathrm{~L}$ & U\&SC & 23 and 27 & up to 56 & 0.012 & 0.086 & Alvarez et al., 2004 \\
\hline Fluoxetine & $\mathrm{U}$ & $200^{\mathrm{e}}$ & 1 POCIS / $3 \mathrm{~L}$ & SBMB (800-900 rpm) & 5,15 and $25^{\mathrm{f}}$ & 8 & 0.433 & $0.484-0.974$ & Li et al., $2010 \mathrm{a}$ \\
\hline Fluoxetine & $\mathrm{U}$ & 229 & 1 POCIS / $3 \mathrm{~L}$ & U\&SC & 22 and $28^{\mathrm{h}}$ & up to 29 & 0.223 & 1.37 & MacLeod et al., 2007 \\
\hline Gemfibrozil & $\mathrm{U}$ & $200^{\mathrm{e}}$ & 1 POCIS / $3 \mathrm{~L}$ & SBMB (800-900 rpm) & 5,15 and $25^{\mathrm{f}}$ & 8 & 0.222 & $0.257-0.350$ & Li et al., 2010a \\
\hline Gemfibrozil & $\mathrm{U}$ and $\mathrm{S}$ & n.d. ${ }^{\text {d }}$ & 1 POCIS / 2 L & SBMB & 15 and 21 & 10 & - & $0.054^{\mathrm{c}}$ & Togola and budzinski, 2007 \\
\hline Gemfibrozil & U & 229 & 1 POCIS / $3 \mathrm{~L}$ & $\mathrm{U} \& \mathrm{SC}$ & 22 and $28^{\mathrm{h}}$ & up to 29 & 0.112 & 0.192 & MacLeod et al., 2007 \\
\hline Ibuprofen & $\mathrm{U}$ & $200^{\mathrm{e}}$ & 1 POCIS / $3 \mathrm{~L}$ & SBMB (800-900 rpm) & 5,15 and $25^{\mathrm{f}}$ & 8 & 0.197 & $0.204-0.348$ & Li et al., 2010a \\
\hline Ibuprofen & $\mathrm{U}$ and $\mathrm{S}$ & n.d. ${ }^{d}$ & 1 POCIS / 2 L & SBMB & 15 and 21 & 10 & - & $0.096^{\mathrm{c}}$ & Togola and budzinski, 2007 \\
\hline Imipramine & $\mathrm{U}$ and $\mathrm{S}$ & n.d. ${ }^{\mathrm{d}}$ & 1 POCIS / 2 L & SBMB & 15 and 21 & 10 & - & $0.404^{\mathrm{c}}$ & Togola and budzinski, 2007 \\
\hline Ketoprofen & $\mathrm{U}$ and $\mathrm{S}$ & n.d. ${ }^{\mathrm{d}}$ & 1 POCIS / $2 \mathrm{~L}$ & SBMB & 15 and 21 & 10 & - & $0.286^{\mathrm{c}}$ & Togola and budzinski, 2007 \\
\hline Ketoprofen & U & 229 & 1 POCIS / $3 \mathrm{~L}$ & $\mathrm{U} \& \mathrm{SC}$ & 22 and $28^{\mathrm{h}}$ & up to 29 & 0.083 & 0.135 & MacLeod et al., 2007 \\
\hline Levothyroxine & n.d. & 180 & 1 POCIS / $1 \mathrm{~L}$ & $\mathrm{U} \& \mathrm{SC}$ & 23 and 27 & up to 56 & 0.009 & 0.053 & Alvarez et al., 2004 \\
\hline Metoprolol & $\mathrm{U}$ & $200^{\mathrm{e}}$ & 1 POCIS / $3 \mathrm{~L}$ & SBMB (800-900 rpm) & 5,15 and $25^{\mathrm{f}}$ & 8 & 0.156 & $0.309-0.465$ & Li et al., 2010a \\
\hline Metoprolol & $\mathrm{U}$ & 229 & 1 POCIS / $3 \mathrm{~L}$ & U\&SC & 22 and $28^{\mathrm{h}}$ & up to 29 & 0.097 & 0.599 & MacLeod et al., 2007 \\
\hline Naproxen & $\mathrm{U}$ & $200^{\mathrm{e}}$ & 1 POCIS $/ 3 \mathrm{~L}$ & SBMB (800-900 rpm) & 5,15 and $25^{\mathrm{f}}$ & 8 & 0.2 & $0.239-0.392$ & Li et al., 2010a \\
\hline Naproxen & $\mathrm{U}$ and $\mathrm{S}$ & n.d. ${ }^{\mathrm{d}}$ & 1 POCIS / $2 \mathrm{~L}$ & SBMB & 15 and 21 & 10 & - & $0.144^{\mathrm{c}}$ & Togola and budzinski, 2007 \\
\hline Omeprazole & n.d. & 180 & 1 POCIS / $1 \mathrm{~L}$ & U\&SC & 23 and 27 & up to 56 & 0.007 & 0.03 & Alvarez et al., 2004 \\
\hline Omeprazole & $\mathrm{U}$ & 229 & 1 POCIS / $3 \mathrm{~L}$ & U\&SC & 22 and $28^{\mathrm{h}}$ & up to 29 & n.d. & 2.46 & MacLeod et al., 2007 \\
\hline Oxytetracycline & Artificial S & n.d. ${ }^{\mathrm{d}}$ & 1 POCIS / 2 L & SBMB & 21 & 7 & - & 0.023 & Martinez Bueno et al., 2009 \\
\hline Paroxetine & $\mathrm{U}$ & $200^{\mathrm{e}}$ & 1 POCIS / $3 \mathrm{~L}$ & SBMB (800-900 rpm) & 5,15 and $25^{\mathrm{f}}$ & 8 & 0.605 & $0.905-0.987$ & Li et al., 2010a \\
\hline
\end{tabular}




\begin{tabular}{|c|c|c|c|c|c|c|c|c|c|}
\hline Paroxetine & $\mathrm{U}$ & 229 & 1 POCIS / $3 \mathrm{~L}$ & U\&SC & 22 and $28^{\mathrm{h}}$ & up to 29 & n.d. & 0.883 & MacLeod et al., 2007 \\
\hline Propanolol & $\mathrm{U}$ & $200^{\mathrm{e}}$ & 1 POCIS / $3 \mathrm{~L}$ & SBMB (800-900 rpm) & 5,15 and $25^{\mathrm{f}}$ & 8 & 0.271 & $0.484-0.917$ & Li et al., $2010 \mathrm{a}$ \\
\hline Propanolol & $\mathrm{U}$ & 229 & 1 POCIS / $3 \mathrm{~L}$ & $\mathrm{U} \& \mathrm{SC}$ & 22 and $28^{\mathrm{h}}$ & up to 29 & 0.147 & 0.98 & MacLeod et al., 2007 \\
\hline Terbutalin & $\mathrm{U}$ and $\mathrm{S}$ & n.d. ${ }^{d}$ & 1 POCIS / 2 L & SBMB & 15 and 21 & 10 & - & $0.166^{\mathrm{c}}$ & Togola and budzinski, 2007 \\
\hline Tetracycline & Artificial S & n.d. ${ }^{d}$ & 1 POCIS / 2 L & SBMB & 21 & 7 & - & 0.071 & Martinez Bueno et al., 2009 \\
\hline Venlafaxine & $\mathrm{U}$ & $200^{\mathrm{e}}$ & 1 POCIS / $3 \mathrm{~L}$ & SBMB (800-900 rpm) & 5,15 and $25^{f}$ & 8 & 0.104 & $0.167-0.521$ & Li et al., 2010a \\
\hline Venlafaxine $\mathrm{N}^{\mathrm{g}}$ & $\mathrm{U}$ & $200^{\mathrm{e}}$ & 1 POCIS / $3 \mathrm{~L}$ & SBMB (800-900 rpm) & 5,15 and $25^{\mathrm{f}}$ & 8 & 0.187 & $0.133-0.408$ & Li et al., 2010a \\
\hline Venlafaxine $\mathrm{O}^{\mathrm{g}}$ & $\mathrm{U}$ & $200^{\mathrm{e}}$ & 1 POCIS / $3 \mathrm{~L}$ & SBMB (800-900 rpm) & 5,15 and $25^{\mathrm{f}}$ & 8 & 0.179 & $0.158-0.396$ & Li et al., 2010a \\
\hline Triclosan & $\mathrm{U}$ & $200^{\mathrm{e}}$ & 1 POCIS / $3 \mathrm{~L}$ & SBMB (800-900 rpm) & 5,15 and $25^{\mathrm{f}}$ & 8 & 0.753 & $1.006-1.929$ & Li et al., 2010a \\
\hline Triclosan & $\mathrm{U}$ & 229 & 1 POCIS / $3 \mathrm{~L}$ & $\mathrm{U} \& \mathrm{SC}$ & 22 and $28^{\mathrm{h}}$ & up to 29 & 0.184 & 1.92 & MacLeod et al., 2007 \\
\hline
\end{tabular}

\section{n.d. : Not defined}

- : Not tested

a: U: Ultrapure Water; T: Tap Water; S: Seawater

${ }^{\mathrm{b}}$ : SBMB: Stirred by magnetic bar; FTS: Flow-through system; U\&SC: Unstirred and stirred conditions; RT: Renewal time

${ }^{c}$ : Mean Rs for different temperature and salinity conditions and for $200 \mathrm{mg}$ of sorbent

d: Pharmaceutical POCIS configuration by Exposmeter (Tavelsjö, Sweden)

e: POCIS configuration by Environmental Sampling Technologies (St Joseph, USA)

$: 5,15$ and $25^{\circ} \mathrm{C}$ for stirred and $25^{\circ} \mathrm{C}$ for unstirred exposures

: $\mathrm{N}=$ Venlafaxine $\mathrm{N}$-desmethyl, $\mathrm{O}=$ Venlafaxine $\mathrm{O}$-desmethy

$\mathrm{h}: 22^{\circ} \mathrm{C}$ for unstirred and $28^{\circ} \mathrm{C}$ for stirred exposures 
Table 5 : Review of experimental parameters reported during Rs calibration experiments of polar organic contaminant integrative samplers (POCIS) for alkylphenols and pesticides (with pharmaceutical configuration of POCIS only).

\begin{tabular}{|c|c|c|c|c|c|c|c|c|c|}
\hline Chemicals & Water $^{\mathrm{a}}$ & $\begin{array}{l}\text { POCIS Surf. area } \\
\text { /mass of sorbent }\end{array}$ & $\begin{array}{l}\text { Experimental } \\
\text { design }\end{array}$ & Flowing conditions ${ }^{\mathbf{b}}$ & Temp. & Exposure & Rs Quiescent & Rs Flowing & Ref. \\
\hline & & $\left(\mathrm{cm}^{2} / \mathrm{g}\right)$ & & & $\left({ }^{\circ} \mathrm{C}\right)$ & (Day) & (L/day) & (L/day) & \\
\hline 4-NP & $\mathrm{U}$ & n.d. ${ }^{d}$ & 1 POCIS / $1 \mathrm{~L}$ & SBMB (350 rpm) & 23.5 & up to 28 & - & 0.117 & Arditsoglou and Voutsa, 2008 \\
\hline 4-NP & $\mathrm{U}$ & $200^{\mathrm{e}}$ & 1 POCIS / 3 L & SBMB (800-900 rpm) & 5,15 and $25^{\mathrm{f}}$ & 8 & 0.923 & $1.199-2.459$ & Li et al., 2010a \\
\hline $4-\mathrm{OP}$ & $\mathrm{U}$ & n.d. ${ }^{d}$ & 1 POCIS / $1 \mathrm{~L}$ & SBMB (350 rpm) & 23.5 & up to 28 & - & 0.1 & Arditsoglou and Voutsa, 2008 \\
\hline $4-\mathrm{OP}$ & Filtered S & $180^{\mathrm{d}}$ & POCIS in $200 \mathrm{~L}^{\mathrm{g}}$ & FTS $(4 \mathrm{~cm} / \mathrm{s})$ & 10 & up to 28 & - & 0.058 & Harman et al., 2008a \\
\hline BPA & $\mathrm{U}$ & n.d. ${ }^{d}$ & $1 \mathrm{POCIS} / 1 \mathrm{~L}$ & $\operatorname{SBMB}(350 \mathrm{rpm})$ & 23.5 & up to 28 & - & 0.117 & Arditsoglou and Voutsa, 2008 \\
\hline BPA & $\mathrm{U}$ & $200^{\mathrm{e}}$ & 1 POCIS / $3 \mathrm{~L}$ & SBMB (800-900 rpm) & 5,15 and $25^{\mathrm{f}}$ & 8 & 0.482 & $0.531-0.835$ & Li et al., 2010a \\
\hline BPA & $\mathrm{U}$ and $\mathrm{S}$ & 115 & 3 POCIS / $30 \mathrm{~L}$ & FTS (with RT of $23.8 \mathrm{~h}$ ) & 15 & up to 10 & - & $0.04^{\mathrm{c}}$ & Zhang et al., 2008 \\
\hline NP2EO & U & n.d. ${ }^{d}$ & 1 POCIS / $1 \mathrm{~L}$ & SBMB (350 rpm) & 23.5 & up to 28 & - & 0.117 & Arditsoglou and Voutsa, 2008 \\
\hline NP1EO & $\mathrm{U}$ & n.d. ${ }^{d}$ & 1 POCIS / $1 \mathrm{~L}$ & SBMB (350 rpm) & 23.5 & up to 28 & - & 0.09 & Arditsoglou and Voutsa, 2008 \\
\hline Acetochlor & $\mathrm{T}$ & 200 & 3 POCIS / $80 \mathrm{~L}$ & FTS $(2-3 \mathrm{~cm} / \mathrm{s})$ & 17 & 21 & - & 0.225 & Mazzella et al., 2007 \\
\hline Atrazine & $\mathrm{T}$ & 200 & 3 POCIS / $80 \mathrm{~L}$ & FTS $(2-3 \mathrm{~cm} / \mathrm{s})$ & 17 & 21 & - & 0.239 & Mazzella et al., 2007 \\
\hline Atrazine & Artificial S & n.d. ${ }^{d}$ & 1 POCIS / 2 L & SBMB & 21 & 7 & - & 0.214 & Martinez Bueno et al., 2009 \\
\hline DIA & $\mathrm{T}$ & 200 & 3 POCIS / $80 \mathrm{~L}$ & FTS $(2-3 \mathrm{~cm} / \mathrm{s})$ & 17 & 21 & - & 0.064 & Mazzella et al., 2007 \\
\hline DEA & $\mathrm{T}$ & 200 & 3 POCIS / $80 \mathrm{~L}$ & FTS $(2-3 \mathrm{~cm} / \mathrm{s})$ & 17 & 21 & - & 0.122 & Mazzella et al., 2007 \\
\hline Diuron & $\mathrm{T}$ & 200 & 3 POCIS / $80 \mathrm{~L}$ & FTS $(2-3 \mathrm{~cm} / \mathrm{s})$ & 17 & 21 & - & 0.247 & Mazzella et al., 2007 \\
\hline Diuron & n.d. & 180 & 1 POCIS / $1 \mathrm{~L}$ & U\&SC & 23 and 27 & up to 56 & 0.005 & 0.045 & Alvarez et al., 2004 \\
\hline Diuron & Artificial S & n.d. ${ }^{d}$ & 1 POCIS / 2 L & SBMB & 21 & 7 & - & 0.086 & Martinez Bueno et al., 2009 \\
\hline Isoproturon & $\mathrm{T}$ & 200 & 3 POCIS / $80 \mathrm{~L}$ & FTS $(2-3 \mathrm{~cm} / \mathrm{s})$ & 17 & 21 & - & 0.218 & Mazzella et al., 2007 \\
\hline Isoproturon & n.d. & 180 & 1 POCIS / $1 \mathrm{~L}$ & $\mathrm{U} \& \mathrm{SC}$ & 23 and 27 & up to 56 & 0.015 & 0.086 & Alvarez et al., 2004 \\
\hline Metoxuron & $\mathrm{T}$ & 200 & 3 POCIS / $80 \mathrm{~L}$ & FTS $(2-3 \mathrm{~cm} / \mathrm{s})$ & 17 & 21 & - & 0.198 & Mazzella et al., 2007 \\
\hline Simazine & $\mathrm{T}$ & 200 & 3 POCIS / $80 \mathrm{~L}$ & FTS $(2-3 \mathrm{~cm} / \mathrm{s})$ & 17 & 21 & - & 0.21 & Mazzella et al., 2007 \\
\hline Simazine & Artificial S & n.d. ${ }^{d}$ & 1 POCIS / 2 L & SBMB & 21 & 7 & - & 0.223 & Martinez Bueno et al., 2009 \\
\hline Terbutryn & Artificial S & n.d. ${ }^{d}$ & 1 POCIS / 2 L & SBMB & 21 & 7 & - & 0.141 & Martinez Bueno et al., 2009 \\
\hline Terbuthylazine & $\mathrm{T}$ & 200 & 3 POCIS / $80 \mathrm{~L}$ & FTS $(2-3 \mathrm{~cm} / \mathrm{s})$ & 17 & 21 & - & 0.251 & Mazzella et al., 2007 \\
\hline Irgarol & Artificial S & n.d. ${ }^{d}$ & 1 POCIS / 2 L & SBMB & 21 & 7 & - & 0.129 & Martinez Bueno et al., 2009 \\
\hline
\end{tabular}

\section{n.d. : Not defined}

- : Not tested

: U: Ultrapure Water; T: Tap Water; S: Seawater

: SBMB: Stirred by magnetic bar; FTS: Flow-through system; U\&SC: Unstirred and stirred conditions; RT: Renewal time

c: Mean Rs for different temperature and salinity conditions and for $200 \mathrm{mg}$ of sorbent

d: Pharmaceutical POCIS configuration by Exposmeter (Tavelsjö, Sweden)

e : POCIS configuration by Environmental Sampling Technologies (St Joseph, USA)

f 5,15 and $25^{\circ} \mathrm{C}$ for stirred and $25^{\circ} \mathrm{C}$ for unstirred exposures

: POCIS placed using a randomised block desing not described 
Table 6: Environmental Quality Standards (EQS) defined by the EU Water Framework Directive (2000) for marine and estuarine (transitional) waters.

\begin{tabular}{clc}
\hline Chemicals & \multicolumn{1}{c}{ Use } & EQS marine waters \\
\hline & & $\mu \mathrm{g} / \mathrm{l}$ \\
4-Nonylphenol (4-NP) & Non ionic detergent metabolite & 0.3 \\
4-tert-Octylphenol (4-OP) & Non ionic detergent metabolite & 0.2 \\
Atrazine & Herbicide & 0.6 \\
Simazine & Herbicide & 1.0 \\
Alachlor & Herbicide & 0.3 \\
Diuron & Herbicide & 0.2 \\
Isoproturon & Herbicide & 0.3 \\
\hline
\end{tabular}

\section{Figures}

Figure 1. Sampling sites along the French Mediterranean coast (Gulf of Lions, France).

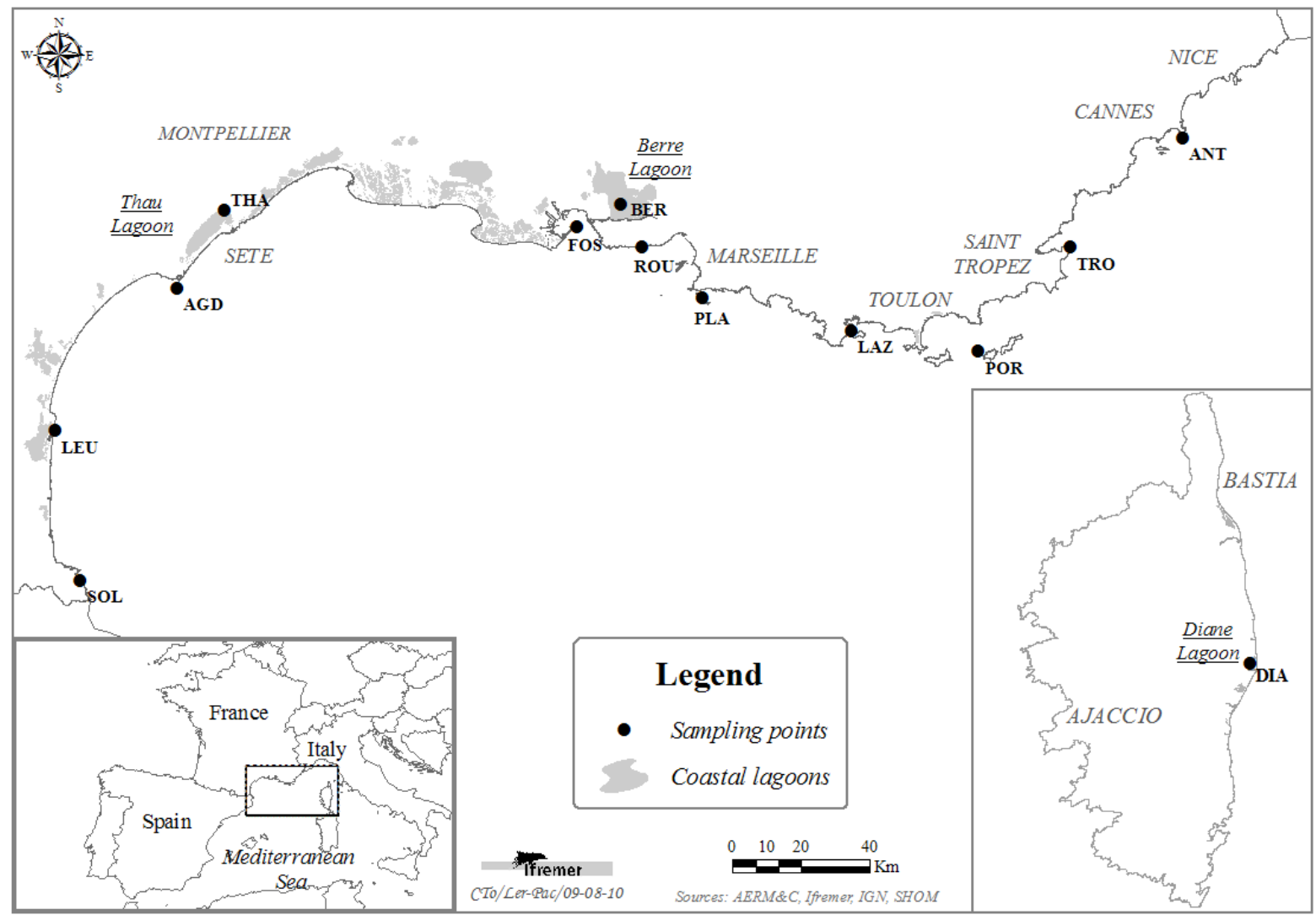


Figure 2. Ambient concentrations (or Time Weighted Average -TWA-Concentrations in $\mathrm{ng} / \mathrm{L})$ of the main pharmaceuticals detected in French Mediterranean coastal waters $(\mathrm{n}=1)$. Caffeine concentrations are shown divided by a factor of 2 .

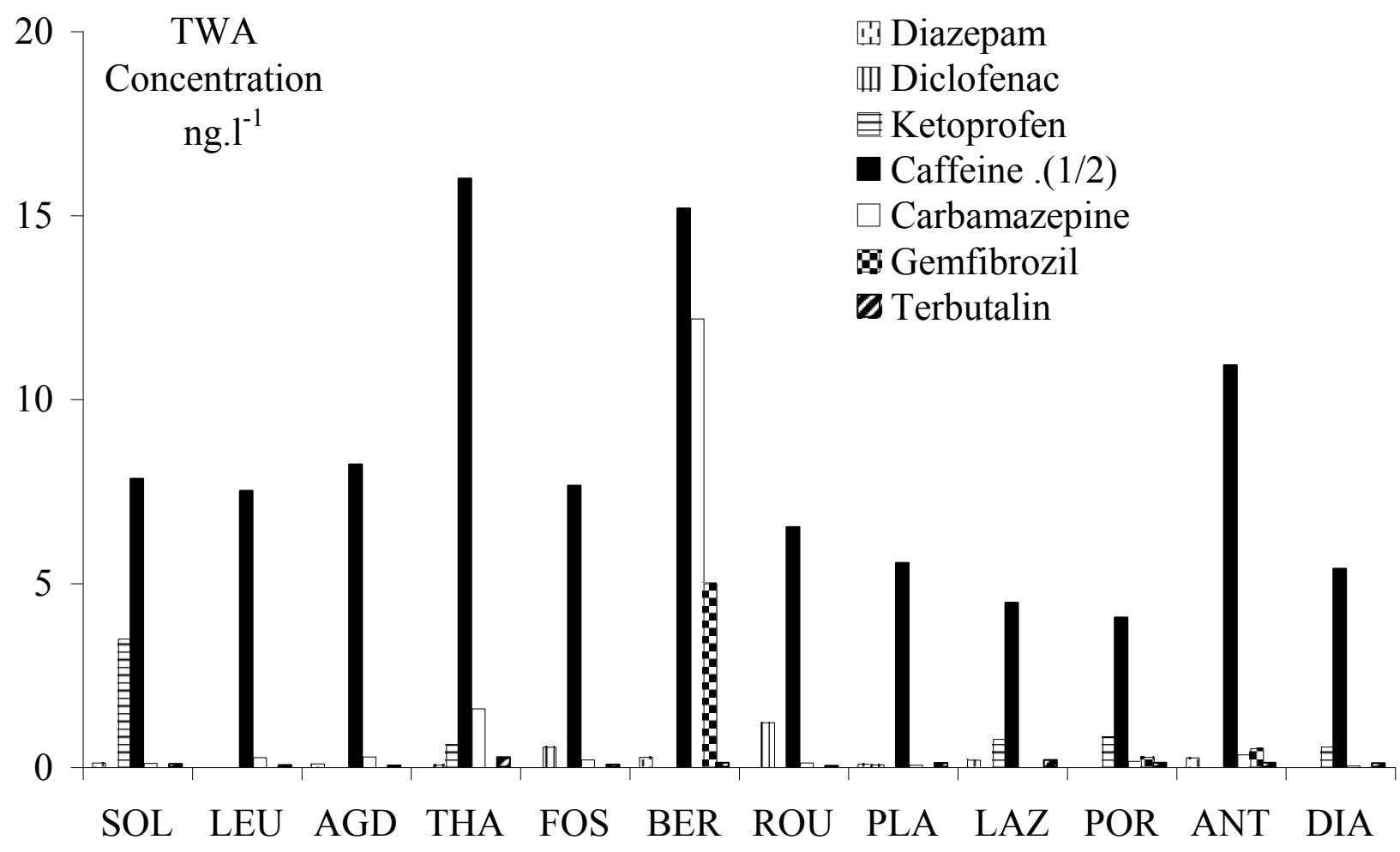


Figure 3. Ambient concentrations (or Time Weighted Average -TWA- Concentrations in $n g / L)$ of the main alkylphenols detected in French Mediterranean coastal waters $(n=1)$.

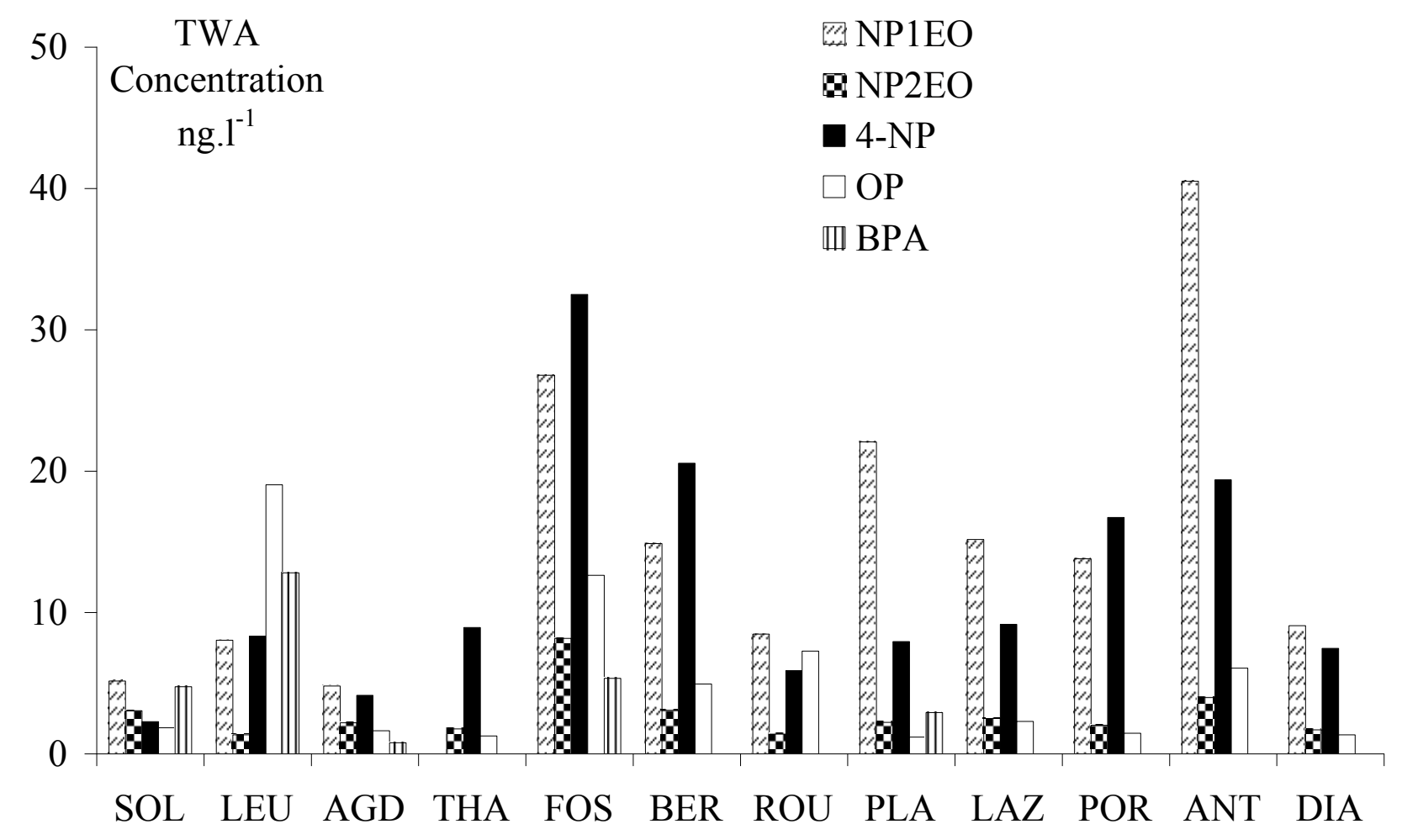


Figure 4. Ambient concentrations (or Time Weighted Average -TWA- Concentrations in $\mathrm{ng} / \mathrm{L})$ of the main pesticides and biocides detected in French Mediterranean coastal waters $(n=4)$.

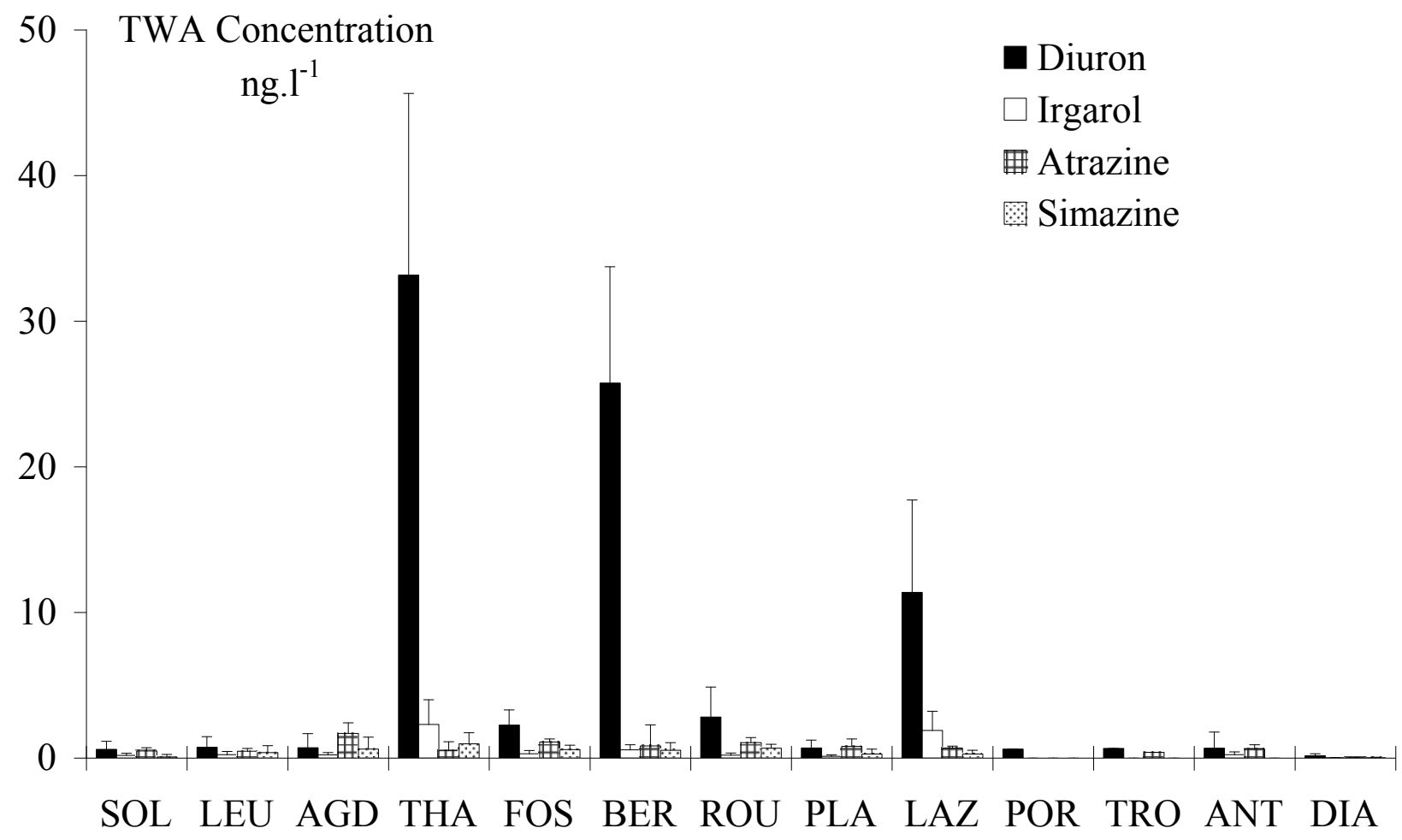

